\title{
A PÓS-GRADUAÇÃO E SUAS INTERLOCUÇÕES COM A EDUCAÇÃO BÁSICA (Des)encontros históricos e manutenção do apartheid socioeducacional ${ }^{1}$
}

\author{
DiLvo I. RistofF* \\ LuCíDIO BIANCHETTI**
}

\begin{abstract}
* Mestre e Doutor em Literatura (University of Southern California), Graduado em Letras (UFRGS). Professor Titular da UFSC. Foi Pró-reitor de Graduação, Diretor de Centro, integrou a Comissão Especial de Avaliação (MEC) e a CONAES. Foi Diretor de Estatísticas e Avaliação da Educação Superior (INEP) e de Educação Básica (CAPES). Foi Reitor pro-tempore da Universidade Federal Fronteira Sul. Um dos fundadores da revista Avaliação. É até hoje editor adjunto dessa revista. Autor, co-autor, organizador de livros, capítulos e de artigos na área de literatura e sobre a temática de educação superior. Florianópolis, SC, Brasil. E-mail: ristoff.dilvo@gmail.com

**Pedagogo, Mestre e Doutor em Educação. Professor na Universidade Federal de Santa Catarina. Excoordenador do PPGE-UFSC. Ex-vice-presidente da ANPED. Pesquisador do CNPq. Pós-doutorado na Universidade do Porto. Autor, organizador e co-autor de vários livros e artigos sobre educação, especialmente sobre educação superior. Florianópolis, SC, Brasil. E-mail: lucidio.bianchetti@pq.cnpq.br
\end{abstract}

Resumo: Por meio deste texto apresentamos alguns elementos e reflexões, visando evidenciar que as interlocuções entre a pós-graduação (PG) e a educação básica (EB) caracterizam-se como (des)encontros históricos e que, no limite, vêm garantindo a manutenção do apartheid socioeducacional desde o Brasil Colônia. A primazia da opção pela educação das elites e a inexistência ou postergação de iniciativas voltadas à educação popular é uma marca dessa trajetória. Do descobrimento, até recentemente, sequer podemos falar em Sistema de Educação, no Brasil, se o entendemos como relação orgânica entre os diversos níveis de ensino, partindo do pré-escolar, passando pela EB, Educação Superior (ES), incluindo a PG. Nossa hipótese é de que, no Brasil, desde os primórdios, sempre se optou e foram mais eficazes as iniciativas para dar conta das necessidades educacionais daqueles que se encontravam/am no ápice da pirâmide social, do que àqueles que se situavam/am nos estratos intermediários e muito menos para o grande contingente que compõe a base da pirâmide. Somente em anos mais recentes, particularmente a partir da redemocratização do país é que percebemos sinais cada vez mais concretos de preocupações com a materialização de um Sistema de Educação, com a dilatação do período obrigatório de escolaridade avançando inclusivamente na direção dos extremos (PG - EB), mas sem deixar de evidenciar que as prioridades que passam a ganhar contornos mais nítidos são, preponderantemente, do ápice para a base, exemplarmente representados pelo surgimento da CAPES, para a ES, na década de 1950 e apenas no início dos anos 2000 é que passa a haver uma preocupação com os estratos sociais/escolaresinferiores, com a criação da Nova CAPES para a EB. Antes disso predominam dualidades estruturais que evidenciam a inclusão mais qualificada de poucos privilegiados e o abandono ou secundamento de muitos que ficaram de fora ou foram incluídos marginalmente. É esse privilegiamento ou primazia, em termos educacionais - mas não só! - de atenção àqueles que ocupam os estratos superiores do sistema educacional brasileiro, que nos autoriza a falar de baixa ou inexistente interlocução entre

1 Uma primeira versão deste texto foi apresentada no decorrer do "IX Seminário de Pesquisa em Educação da Região Sul - IX ANPEdSUL", promovido pelo Programa de Pós-graduação em Educação da Universidade de Caxias do Sul, RS. Os originais dos textos apresentados estão disponíveis no E-book, que se encontra no Portal da ANPEdSUL (www.portalanpedsul.com.br/). Cf.: RAMOS, B. F.; PAVIANI, N. M. S.; AZEVEDO, T M. de (Orgs.). A pós-graduação e suas interlocuções com a educação básica: Múltiplos olhares. Caxias do Sul: Editora da UCS e São Leopoldo: Casa Leiria, 2012 (ISBN: 9788570616579). Ficam aqui registrados nossos agradecimentos à Coordenação da IX ANPEdSUL pela liberação do texto para ser inserido nesta Revista. 
a PG e a EB e a caracterizarmos esse movimento como uma história de desencontros ou também da manutenção de um apartheid socioeducacional. Os dados sobre o pouco feito e o muito a fazer são inequívocos.

Palavras-chave: Pós-graduação e educação básica. Políticas públicas. Formação de professores.

\title{
GRADUATE STUDIES AND THEIR DIALOGUES WITH BASIC EDUCATION:
}

Historical (dis)encounters and the perpetuation of the socio-educational apartheid.

Abstract: Through this paper we present some reflections and elements in order to show that the dialogues between the graduate studies and basic education are characterized as historical (dis)encounters and that, ultimately, have guaranteed the maintenance of the socio-educational apartheid since colonial Brazil. The primacy of choice for the education of the elite and the lack or delay of initiatives related to popular education is the brand of this trajectory. From the discovery of the country until recently, we can hardly speak of an Educational System in Brazil, if we understand it as an organic relationship between the various levels of education, from pre-school, through basic education, to Higher Education, including graduate studies. Our hypothesis is that in Brazil, since its origin, the choice was made in favor of initiatives which addressed the needs of those at the top of the social pyramid, and not in favor of those at the middle and, much less, of the large majority of the population which formed the basis of the pyramid. Only in recent years, particularly since the redemocratization of the country, do we perceive concrete signals of specific concerns with the materialization of a System of Education, with the expansion of the compulsory period of schooling moving indeed toward the extremes (graduate studies - basic education), but not without showing evidence that the priorities gain sharper outlines primarily from the apex to the base, exemplarily represented by the emergence of CAPES, for higher education, in the 1950s, whereas only in the early 2000's a concern is shown with the lower social strata, with the creation of the New CAPES, this time for basic education. Before that, the structural dualities that predominate show that the inclusion of the qualified and privileged few represents the exclusion or marginal inclusion of many. It is this privileging or primacy, in educational terms - but not only! - this attention to those who occupy the upper strata of the Brazilian educational system - which allows us to speak of low or no dialogue between graduate studies and basic education and to characterize this movement as a history of disencounters and also of perpetuation of a socio-educational apartheid. Data on the little that was done and the many things that still need to be done are unmistakable.

Key words: Graduate and basic education. Public policy. Teacher education.

\section{UMA INTERLOCUÇÃO FRACA OU INEXISTENTE: A TÍTULO DE INTRODUÇÃO}

\author{
(Tudo vinha) "... de cima e de fora".
} (Roberto Schwarz, 2012)

"Durante muito tempo a formação dos profissionais
para a educação básica foi entendida como de
responsabilidade de cada indivíduo que atuava na
escola ou nos órgãos gestores das redes públicas de
educação. Esta responsabilidade, que na verdade é
do Estado brasileiro, por muitos anos foi preterida
das políticas, programas e açães dos governos".

[(Excerto de texto dos membros do CTC-EB/CAPES, Mandato 2008 -2010)] 
A partir de apontamentos de caráter mais geral, seguindo uma certa linha de tempo, pretendemos ressaltar alguns aspectos que evidenciam a predominância ou a prevalência, no Brasil, desde o descobrimento, de iniciativas na área da educação e da escolarização, voltadas a atender um contingente populacional reduzido e situado no ápice da pirâmide social, paralelamente ao abandono e à assunção de medidas secundárias, resultando em abandono ou na dispensa de cuidados míninos aos componentes dos outros estratos da população, especialmente àqueles que se situavam nos estratos inferiores da pirâmide social. Desde a opção e responsabilização dos jesuítas pela educação das elites, até período mais recente, em termos qualitativos e quantitativos, registraram-se poucos pontos fora desta curva ou inflexões que nos permitissem falar da superação de políticas direcionadas a alguns ou de atenuantes na historicamente predominante pedagogia da exclusão.

Em um dos compêndios mais abrangentes e reconhecidamente qualificados de história da pedagogia, o professor italino Franco Cambi, ao explicitar que, de qualquer perspectiva que se analisar esse movimento das iniciativas pedagógicas e da educação sistematizada no decorrer dos tempos, defrontamonos com "vias interrompidas, de possibilidades bloqueadas, de itinerários desprezados que devem ser compreendidos e afirmados e indicados como alternativas possíveis não só do passado, mas também do presente, pelo menos como alternativas teóricas, percursos diferentes, integradores e corretores de um modelo" (1999, p. 38).

Tendo como pano de fundo esta afirmação do pesquisador da história das iniciativas e realizações educacionais no decorrer dos tempos e voltando-nos particularmente para a situação do Brasil Colônia, Império e República, podemos começar com uma discordância: falar em "vias interrompidas" significa referir-se a iniciativas, tentativas que não prosperaram. E isto não é de todo verdade quando nos referimos à "história da educação brasileira ou da educação no Brasil”" (RIBEIRO, 1984; ROMANELLI, 1986). Falar de interrupções significaria admitir que efetivamente iniciativas foram tomadas e que de alguma forma ou por algum motivo, foram suspensas ou suprimidas. Ora, não é exatamente o que podemos falar, particularmente da educação brasileira, voltada aos estratos inferiores da população.

No tocante à sequência da citação, se tivermos presente que a chegada dos jesuítas, pioneiros no encargo de assumir a educação na Colônia, se dá em um período de convulsões no contexto europeu, sacudido pelos embates dos movimentos reformistas e contra-reformistas, então, sim, podemos falar de bloqueamentos, de alternativas não levadas em conta ou de itinerários que 
não foram seguidos. Do que estaríamos autorizados a falar seria da implementação de duas linhas, duas posturas, dois itinerários, com perspectivas diferentes daquilo que vinha sendo a postura hegemônica esposada pela igreja católica por um longo período, desde a Idade Média. O movimento reformista cindiu a igreja e passou-se a percorrer trajetórias diferentes por parte dos movimentos que buscavam manter a ordem estabelecida e daqueles que queriam radicalizar em novas direções. E isto abrangeu o leque de frentes com as quais a sociedade, no Renascimento, defrontava-se. No tocante especificamente à educação, voltando a Cambi (1999), vamos encontrar semelhanças e diferenças entre os reformadores e os contra-reformadores, traduzidas nos seguintes aspectos:

O primeiro (movimento) privilegia a instrução dos grupos burgueses e populares com o fim de criar as condições mínimas para uma leitura pessoal dos textos sagrados, enquanto o segundo, sobretudo com a obra dos jesuítas, repropõe um modelo cultural e formativo tradicional em estreita conexão com o modelo político e social expresso pela classe dirigente (p. 256).

E este é o aspecto que nos interessa abordar: da parte dos jesuítas, dentre os pioneiros e principais agentes da Contra-reforma, teremos a reafirmação de ideais, valores, perspectivas que apontavam para o passado. E se muitas 'armas' foram utilizadas para tentar barrar a Reforma, como a reafirmação do tribunal da inquisição, dos dogmas, da autoridade de Roma, entre outras medidas, particularmente aqui nos interessa o redirecionamento que foi dado, no Concílio de Trento ${ }^{2}$, ao carisma da "Companhia de Jesus", criada por Inácio de Loyola (1491 - 1556): de padres guerreiros para libertar os lugares santos, no Oriente, das mãos dos árabes, sarracenos, muçulmanos ou que denominação se desse aos 'hereges', passam a receber a missão de tornarem-se "padres educadores", uma vez que uma das pedras de toque do sucesso do movimento reformista era a preocupação com a alfabetização, embora com uma vertente vicária no sentido de que os seguidores pudessem ter acesso direto às sagradas escrituras, sem a mediação imediata de padres ou dos grandes santos da igreja, com seu trabalho de explicar o significado das lições bíblicas ou glosar os textos, a fim de que se garantisse uma leitura sem chances da temerária livre interpretação.

2 Reuniões da cúpula da igreja católica para tratar de questões que exigem posicionamentos. No caso deste Concílio realizado na cidade de Trento, entr 1545 e 1564, as discussões e decisões voltaram-se aos 'estragos' que o movimento desencadeado por Lutero (1483 - 1546) e seguido por outros reformistas, estava provocando no interior da igreja romana. 
O movimento reformista terá na Didática Magna ou da arte de ensinar tudo a todos, de João Amós Comenius (1592 - 1670) a síntese mais apurada do que se pretendia com a educação: "Ensinar tudo a todos" ${ }^{3}$. O movimento Contra-reformista, fará da Companhia de Jesus sua principal ponta de lança, seu porta-voz, seu exército catequético-educador e, seja na Península Ibérica, seja seguindo os ibérios pelos mares onde quer que portugueses e espanhóis aportassem, lá estavam os inacianos para implementar o ministério e o magistério. Assumiram como principal missão, a evangelização e a educação. Para essas tarefas, a principal 'arma', além da catequização, era a educação, sintetizadas na Ratio Studiorum ${ }^{4}$, uma espécie de plano pedagógico que deveria ser seguido, sem contestações, onde quer que os Jesuítas assumissem a missão de evangelizar, catequizar e educar, tarefas com divisas de difícil demarcação, uma vez que eram colocadas em prática concomitantemente.

Manacorda (1989, p. 202), falando das missões da Companhia de Jesus, em termos gerais, afirma:

No fim do século (1586-99) apareceu a Ratio studiorum, que regulamentou rigorosamente todo o sistema escolástico jesuítico: a organização de classes, os horários, os programas e as disciplinas. Eram previstos seis anos de studia inferiora, divididos em cinco cursos (três de gramática, um de humanidades ou poesia, um de retórica); um triênio de studia superiora de filosofia (lógica, física, ética), um ano de metafísica, matemática superior, psicologia e fisiologia. Após uma repetitio generalis e um período de prática de magistério, passava-se ao estudo da teologia, que durava quatro anos.

Esses são alguns dados e aspectos que desvelam a forma como os habitantes da nova Colônia vão receber os colonizadores, ser submetidos e, na particularidade da presença dos jesuítas, vão ser catequizados e educados e isto, sob os parâmetros contidos na Ratio Studiorum.

$3 \mathrm{O}$ aprofundamento na leitura da obra, no entanto, irá evidenciar os vínculos, seja do movimento reformista, seja do pastor da Morávia, o quanto estavam cercados pelos limites do tempo. Ao explicitar o detalhamento da sua reforma educacional, Comenius prescreve a educação primária para todos; a escola de latim para alguns e a academia para poucos. Afinal, dizia ele, que esta deveria ser frequentada apenas pelos mais capazes, "pelos melhores engenhos, pela flor dos homens", uma vez que nem todos nasceram para acessar a universidade. E se alguns eram privilegiados e podiam aspirar o ingresso na academia, a maioria deveria ser enviados à lavoura, "para as profissões manuais, para o que, afinal nasceram" (COMENIUS, 1985, p. 173)

4 Teve sua redação iniciada na primeira metade do século XVI. No entanto sua aprovação definitiva somente veio a ocorrer em 1599. Caracteiza-se como um receituário minuncioso, prescrevendo o que deveria ser feito pelos católicos em geral, mas mais especificamente pelos internos dos colégios fundados pelos jesuítas, por onde quer que fossem. Afinal, eles tinham a primazia na defesa dos ideais católicos esposados pelo Vaticano e, pela origem etimológica, "católico" carrega a pretenção de "universal". 
E aqui terão o monopólio absoluto da educação (incluindo o ministério) e da escolarização, até serem expulsos pelo Marquês de Pombal ${ }^{5}$, em 1749. Passados 200 anos de responsabilização pela educação no Brasil, ao serem expulsos, conforme Marcílio (apud SAVIANI, 2007a, p. 441), o somatório de alunos de todas as instituições jesuíticas, não atingia $0,1 \%$ da população da Colônia, acrescentando-se que neste percentual estavam excluídos/as: - Mulheres (50\% da população brasileira); - Escravos (40\% da população brasileira); - Negros livres; - Pardos; - Filhos ilegítimos e Crianças abandonadas.

Embora algumas medidas tenham sido tomadas, a partir daí, em termos de políticas de responsabilização pela instrução pública, houve poucos avanços no sentido de uma inclusão mais significativa da população no processo de escolarização. Sem contar que se passarão poucos anos para que a decisão de retorno dos jesuitas ${ }^{6}$ seja tomada e pouco sucederá em termos de novidades até a transferência da família real portuguesa para o Brasil, em 1808. Nesse momento passam a ser tomadas medidas em termos de implementação de iniciativas educacionais na ex-Colônia, agora elevada à categoria de "Reino Unido a Portugal e Algarves", mas que se voltam, predominantemente, às necessidades da Coroa e ao séquito formado pela Corte, que aqui se transferiram juntamente com D. João VI (1767 - 1826) e família, como veremos posteriormente. Exemplarmente podem-se citar os cursos de cirurgia, direito, mineralogia, navegação entre outros.

Uma novidade no período de permanência dos reis portugueses foi a criação do "Imperial Colégio de Pedro II", em 1837, uma espécie de ginásio, que embora não estivesse fechado para os 'despossuídos', privilegiava a elite para poder instruir e formar, naquele nível, comerciantes, industriais e funcionários para as repartições públicas. Após essa formação eles poderiam continuar os estudos no esquema previsto na Ratio Studiorum, alguns no Brasil, mas em sua maioria no Velho Mundo.

$\mathrm{Na}$ República medidas serão tomadas para ampliar o alcance público da instrução pública, cabendo muito mais aos estados e municípios a responsabilidade pela educação primária e secundária e iniciativas serão tomadas em termos de criação de faculdades e com a agregação destas, de universidades, constituindose algumas exceções nesse processo como é o caso da Universidade do Brasil, a Universidade de São Paulo e, posteriormente a Universidade de Brasília.

5 Título atribuído a Sebastião José de Carvalho e Melo (1699 -1782), considerado um iluminista e que considerou pífios os resultados da atuação dos jesuítas, apesar de contarem com $10 \%$ dos impostos aqui recolhidos para cuidar da educação e da conversão dos gentios, bem como não concordar com o poder e as posses que desfrutavam e haviam acumulado. Mais detalhes, cf. Bianchetti (2011).

6 Isto ocorrerá no reinado de Maria I (1734 - 1816), que sucedeu seu pai, o Rei José I. 
Mas sejam quais forem as medidas que têm sido tomadas, predominaram as opções voltadas à Educação Superior (ES) em relação aos outros graus de ensino e a preferência por atender os integrantes do estrato superior da pirâmide social, com indisfarçada secundarização aos estratos mais baixos da população e no que diz respeito à educação primária e secundária.

A partir da metade dos anos de 1990 haverá uma série de medidas que dilatarão as preocupações com os extremos, da pré-escola à pós-graduação, com a Criação da CAPES e a promulgação das Leis de Diretirzes e Bases (4024/61 e 9394/96), com indicações e iniciativas concretas da implantação de um sistema de educação e ensino, aspecto que ou não existia ou demorou para insinuar-se, conforme Saviani (2008) na obra Educação Brasileira. Estrutura e Sistema, por meio da qual o autor procura responder se temos ou não um sistema educacional no Brasil.

Voltaremos a estas questões posteriormente.

\title{
2. A EDUCAÇÃO BRASILEIRA OU NO BRASIL DESDE SEUS PRIMÓRDIOS: ALGUNS ELEMENTOS DE CONTEXTO E ESPECIFICIDADES DO SISTEMA
}

\author{
"Todos [...] são iguais, \\ mas há alguns que são \\ mais iguais do que os outros".
}

(George Orwell, 2007)

Quando, em 1549, aporta no Brasil, a expedição de Tomé de Sousa, nela estava um grupo de padres jesuítas, liderados por Manuel da Nóbrega (1517 1570), com a missão catequizadora e educadora dos filhos dos conquistadores e dos povos autóctones, selvagens que precisavam ser educados e salvos. E os componentes da missão jesuítica não somente traziam os ideais da contrareforma em geral, como as prescrições da Ratio Studiorum para serem implantadas, juntamente com a abertura de missões e a fundação de colégios.

\subsection{Dualidades estruturais de contexto e da escolarização}

Nas suas 'bagagens' traziam o firme propósito de em terrae brasilis implantar a Ratio Studiorum, conforme as prescrições emanadas de Roma. Ao chegarem, deparam-se com potenciais 'alunos' que apresentavam defasagens intransponíveis a serem supridas para que o primeiro degrau do esquema original da Ratio, pudesse ser colocado em prática. Manuel da Nóbrega apercebe-se 
disso e ensaia um plano alternativo ao da Ratio, inserindo uns passos prévios, uns antecedentes, que poderiam ser chamado de 'cursinho supletivo ou preparatório ou compensatório', visando habilitar os 'brasileiros' a encaixarem-se no universal plano prescritivo da Ratio.

No esquema ao lado, aparece, à direita, o plano clássico, previsto na Ratio Studiorum, para ser aplicado em todas as partes do mundo onde os jesuítas estivessem, acompanhando os colonizadores. À esquerda aparece a alternativa proposta a fim de preparar os nativos e os descendentes dos portugueses a habilitarem-se para serem admitidos ao plano clássico e universal da Ratio.

A observação dos esquemas - alternativo e original ao da Ratio - propicia um verdadeiro magistério para ajudar-nos a compreender aspectos da educação/ escolarização brasileira desde os primórdios e que vem ao encontro da problemática que estamos nos propondo a tratar neste texto. Perceba-se que no plano original, o primeiro passo da educação sistematizada, institucionalizada, é o "curso de Humanidades", que seria um ginasial antigo ou, analisando o proposto no século XVI equivaleria hoje à Educação Média. Prevalecia a perspectiva de que os passos anteriores, o ensino do Latim, as lições básicas seriam de responsabilidade do vigário, do tio-padre ou de algum ilustrado autodidata ou que tivesse tido oportunidade de acessar o domínio desses códigos por outros meios que não a escola.

Frente à óbvia constatação ou 'partindo da realidade', Nóbrega e seus pares percebem a necessidade de passos anteriores e por isto é que é proposta a alternativa ${ }^{7}$, que não era algo diferente, mas criaria condições prévias para que os neófitos fossem preparados para encaixar-se no esquema eurocêntrico e, depois seguir o curso 'natural', que, em qualquer das opções, concluía com a "viagem a Roma", garantia de que nenhum desvio, ou heresia subsistiria, caso tivesse se insinuado.

Com todos os reconhecimentos passíveis de serem feitos à percepção de Manuel da Nóbrega e seus pares quanto à necessidade de se 'render à realidade', é impossível deixar de perceber que, na proposta, embora não tenha vingado, está explicitada e assumida formalmente a primeira "dualidade estrutural" daquilo que se poderia denominar como sendo a proposta seminal de sistema educacional brasileiro: após a "escola de ler e escrever" e antecedendo o ingresso no previsto estrato do "curso de humanidades", situa-se a primeira discriminação entre aqueles que são 'bons', pelo critério da aprendizagem do Latim e vão ser preparados para ocuparem o ápice da pirâmide do sistema e aqueles

7 Diga-se de passagem, contudo, que o plano alternativo não foi aceito pelos superiores em Roma e Manuel da Nóbrega perdeu o seu posto de Superior da Companhia no Brasil. 


\section{De Nóbrega}

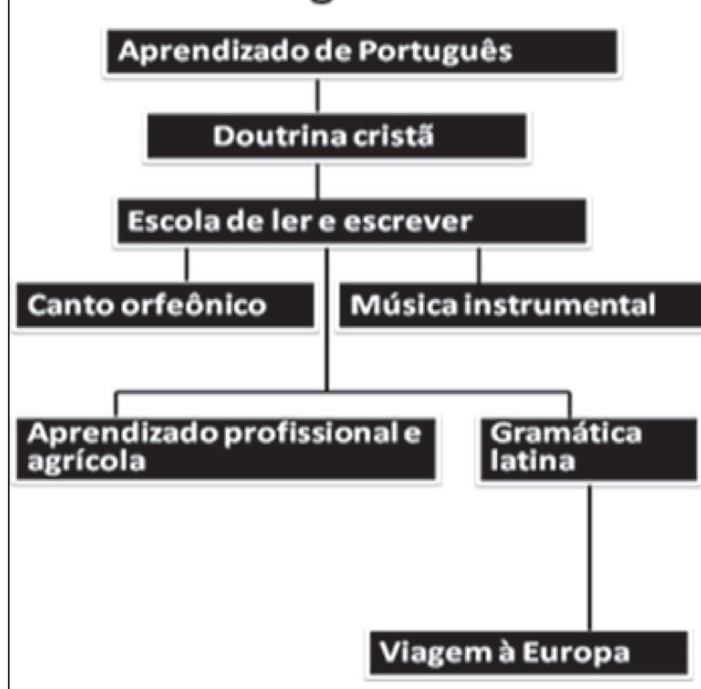

\section{Do Ratio}

\section{Curso de Humanidades}

\section{Curso de Filosofia}

Curso de Teologia

Viagem à Europa

Fonte: Ribeiro (1984)

que não são 'bons da cabeça' e que vão ocupar os estratos intermediários e, principalmente a base da pirâmide, para fazer os trabalhos manuais. Está assim garantida a divisão entre o pensar e o fazer, entre trabalho manual e intelectual, entre homens e não homens, sem nos remetermos ao mundo greco-romano, na escravidão clássica e entre os trabalhadores manuais das lavouras ou do chão de fábrica e os ocupantes do escritório ou dos diretores e gerentes, se pensarmos em períodos mais recentes do predomínio do modo de produção capitalista.

E percebemos aqui uma divisão que não é ideológica, disfarçada, obnubilada, como ocorre atualmente e veremos mais tarde: a segmentação - ou hoje diríamos a exclusão - é explícita e considerada natural. Nada tem a ver com o sistema ou a sociedade. Tudo está relacionado à vontade e às condições dos pretendentes. Pode-se dizer sem a necessidade ou preocupação com a dissimulação.

$\mathrm{Na}$ sequência dessa análise, que guarda as características de linearidade, uma vez que queremos chegar aos dias de hoje tendo alguns parâmetros do passado para entender o presente, apresentamos aquela que consideramos ser a segunda dualidade estrutural do sistema educacional, apenas que agora 
- situando-nos no século XVII -, o 'contorcionismo' verbal é mais exigido, uma vez que a necessidade de mascaramento é maior, embora a discriminação ainda seja explícita. É inclusive por isso que buscamos elementos naquele que é considerado o introdutor da palavra "Ideologia": Destutt de Tracy (1754 1836). Em obra publicada em 1802, ele refere-se à organização da sociedade e à instituição escola nos seguintes termos:

Em toda sociedade civilizada existem, necessariamente, duas classes de pessoas: a que tira sua subsistência da força de seus braços e a que vive da renda de suas propriedades ou do produto de funções, onde o trabalho do espírito prepondera sobre o trabalho manual. A primeira é a classe operária e a segunda é aquela que eu chamaria de classe erudita. Os homens de classe operária têm, desde cedo, necessidade do trabalho de seus filhos. Essas crianças precisam adquirir, desde cedo, o conhecimento e, sobretudo, o hábito do trabalho penoso a que se destinam. Não podem, portanto, perder tempo nas escolas. Os filhos da classe erudita, ao contrário, podem dedicar-se a estudar durante muito tempo. Têm muita coisa para aprender para alcançar o que se espera deles no futuro. Necessitam de certos tipos de conhecimentos que só podem aprender quando o espírito amadurece e atinge determinado grau de desenvolvimento.

Estes são fatos que não dependem de qualquer vontade humana, pois, decorrem, necessariamente, da própria natureza dos homens e da sociedade. Ninguém está em condições de poder mudá-los. Portanto, trata-se de dados invariáveis, dos quais devemos partir.

Concluamos, então, que em todo Estado bem administrado e no qual se dá a devida atenção à educação dos cidadãos, deve haver dois sistemas completos de instrução, um não tendo nada em comum com o outro" (Destutt de Tracy, apud FRIGOTTO, 1986, p. 47). (destaque nosso).

Pensamos que o excerto seja claro o suficiente do quanto é possível dizer, ainda da forma como os clássicos claramente dizem, embora contraditoriamente, o quanto é natural que uns estudem, porque precisarão mais e outros não tenham as mesmas possibilidades porque, supostamente, necessitarão menos dos conhecimentos apreendidos na escola. Afinal, a divisão da sociedade é prévia - e isto sendo natural - não há o que fazer.

A terceira divisão estrutural do sistema - referente ao trabalho e à educação - é aquela introduzida por F. Taylor (1856 - 1915), ao transformar suas anotações resultantes da atuação no chão de fábrica e da sua luta por implantar princípios racionalizadores do trabalho, em termos de um maior aproveitamento do tempo e que deram origem ao livro: Princípios da administração científica (1989), na primeira metade do século XX. Dentre os princípios mais caros do 
Taylorismo destacam-se aqueles que preconizam que: Tudo o que se refere ao planejamento e à concepção é atributo do escritório, dos seus engenheiros, dos especialistas, dos donos das indústrias, dos gerentes; e tudo o que se refere à execução é afeta ao chão de fábrica, aos operários, aos trabalhadores manuais em geral, responsáveis pelo trabalho mais pesado e menos reconhecido e que exige menos preparação intelectual, uma vez que são tarefas repetitivas e são aprendidas pela permanência no posto de trabalho. Enfim, ganha materialidade, contemporaneamente, a versão da premissa greco-romana da divisão entre o homo sapiens e o homo faber.

A quarta divisão estrutural, colocando em evidência novamente a opção pela parte superior da pirâmide, relaciona-se à chegada da família real ao Brasil, em 1808, fugida das ameaças napoleônicas. Na perspectiva mais geral, a possessão ultramarina, da condição de Colônia passa à categoria de "Reino Unido a Portugal e Algarves". Mas o que mais nos interessa aqui é a decisão da Coroa Portuguesa de fazer concessões que até aquela altura não haviam sido pensadas, quanto mais colocadas em prática, que é a criação dos primeiros cursos superiores na (ex)Colônia, destacando-se os de Cirurgia, Direito, Mineralogia, metalurgia e outros, com o pouco disfarçado objetivo de fazer frente às necessidades da coroa portuguesa e assessores - em torno de 15 mil pessoas - que se deslocaram de Portugal para o Brasil.

Se a ES passa a ser uma prioridade, de cujas iniciativas decorrerão o surgimento de faculdades, agregação de faculdades e depois universidades, o mesmo não se pode dizer da EB. Conforme coletânea organizada por Bastos e Mendes $(1999)^{8}$, uma das iniciativas de impacto quantitativo, voltadas à base da pirâmide social e do sistema educacional, foi a disseminação de classes na escola elementar com base no "ensino mútuo" ou "método monitorial" ou o método da "monitoria", que, embora já estivesse presente na Ratio Studiorum, como explicita Mercado (1991) ${ }^{9}$, será sistematizado, na Inglaterra, no século XVIII, por Andrew Bell (1753 - 1832) e Joseph Lancaster (1778 - 1838). Na esteira da expansão da escola elementar levada a efeito na Inglaterra, onde um professor, com o auxílio de monitores - alunos mais avançados - pode dar conta de 'ensinar' a classes numerosas, que, de acordo com os pioneiros Bell e Lancaster, podem ser de 100 a 1000 alunos $^{10}$, entre os anos de 1808 e 1827 ,

8 Nesta coletânea encontra-se o mais completo e detalhado estudo e dados resultantes de pesquisa a respeito do método de Bell e Lancaster e sua implementação em diversos países, com destaque para sua disseminação no Brasil, a partir de 1808.

9 Embora com características e responsabilidades mais voltadas ao controle do comportamento dos colegas, a figura do "decurião" ou do "bedel" - como um proto-monitor -, constavam pioneiramente no plano pedagógico dos Jesuítas (Ratio).

10 Esta proposta ganha respaldo oficial e apoio, basicamente por três motivos: de um lado, há a necessidade 
diversas escolas no município da Corte e nas Províncias, foram criadas, com base nos pressupostos do "ensino mútuo" ou monitorial. A partir desse último ano o método é implantado oficialmente, por meio da Carta de Lei de 15 de outubro de 1827, conhecendo uma grande expansão, até posteriormente refluir, particularmente pela dificuldade de "formar monitores". Porém o importante a ressaltar é o fato de que era necessário ampliar o número de alunos abrangidos 'instruídos', seja para melhorarem suas condições de barganha para ingressar no mercado de trabalho - como havia apontado Adam Smith no seu clássico $A$ riqueza das nações, de 1776 - seja para o domínio mínimo dos códigos civilizados, a fim de que os alunos incorporassem as boas maneiras (civilizadas) para (con)viverem em sociedade.

De outra parte, haverá uma iniciativa que, se voltando à base da pirâmide do sistema educacional, dá origem ao Imperial Colégio Pedro II - como vimos no item 1, acima -, que na verdade, mais do que uma escola com preocupação voltada a atender alunos privilegiados, mesmo que haja menção à preocupação com os 'desvalidos da sorte', direciona-se a alcançar outros objetivos, seja o de garantir emprego para alguns mestres destacados, seja o de servir de modelo, de padrão para os outros poucos colégios já criados ou que viessem a ser institucionalizados no município da Corte ou nas Províncias.

A quinta divisão estrutural vai exigir uma capacidade maior de elaboração para fins de apreendê-la, uma vez que é apresentada de uma forma aliciadora, porém esconde estratégias de transformar o heterogêneo em homogêneo. É no texto "Exclusão includente e inclusão excludente: a nova forma de dualidade estrutural que objetiva as novas relações entre educação e trabalho" (KUENZER, 2005). Esta dualidade também abrange questões do mercado de trabalho e da escolarização. De acordo com Saviani (2007), essas expressões que aparentam ser paradoxais, materializam-se de maneiras que, para serem apreendidas, exigem explicitações um pouco longas, mas que vale acompanhálas, nas palavras do autor:

A "exclusão includente" manifesta-se no terreno produtivo como um fenômeno de mercado. Trata-se das diferentes estratégias que conduzem à exclusão do trabalhador do mercado formal, seguida de sua inclusão na informalidade ou reinclusão no próprio mercado formal.

de domínio dos códigos mínimos relacionados à leitura, à escrita e ao conhecimento dos números para que os alunos-presentes-futuros-trabalhadores tenham condições de fazer as quatro operações matemáticas; de outro há a necessidade de obedecer as leis relativas a um quantum de horas anuais obrigatórias de frequência à escola por parte dos alunos, leis estas que começaram a ser implementadas na Inglaterra no início do século XIX. E, por fim, havia também o interesse dos professores em ampliar numericamente suas classes, uma vez que ganhava destaque o pagamento por aluno. E assim, quanto mais alunos fossem 'incluídos' na escola/classe, maiores seriam os rendimentos do professor. 
Os mecanismos utilizados são a dispensa do trabalhador, que, assim, perde todos os direitos trabalhistas e previdenciários. Excluído, esse trabalhador só pode voltar a ser incluído nas seguintes circunstânias: com carteira assinada, mas com diminuição de salário e de direitos; como empregado de empresa terceirizada; ou trabalhando para a mesma empresa, porém na informalidade. Eis aí a "exclusão includente". A "inclusão excludente", por sua vez, manifesta-se no terreno educativo como a face pedagógica da exclusão includente. Aqui a estratégia consiste em incluir estudantes no sistema escolar em cursos de diferentes níveis e modalidades sem os padrões de qualidade exigidos para o ingresso no mercado de trabalho. Essa forma de inclusão melhora as estatísticas educacionais porque permite apresentar números que indicam a ampliação do atendimento escolar se aproximando da realização de metas como a universalização do acesso ao ensino fundamental. No entanto, para atingir essas metas quantitativas, a política educacional lança mão de mecanismos como a divisão do ensino em ciclos, a progressão continuada, as classes de aceleração que permitem às crianças e jovens permanecer um número maior de anos na escola, sem o correspondente efeito da aprendizagem efetiva. Com isso, embora incluídas no sistema escolar, essas crianças e jovens permanecem excluídas do mercado de trabalho e da participação ativa na vida da sociedade. Consuma-se, desse modo, a "inclusão excludente" (p. 440).

A sexta dualidade a ressaltar refere-se à criação da "Campanha", depois Coordenação de Aperfeiçoamento de Pessoal do Ensino Superior (CAPES), em $1951^{11}$. Mais uma vez percebe-se que o ápice da pirâmide do sistema educacional e, por decorrência, da sociedade, são os destinatários de uma política pública, voltada a uma minoria: preferencialmente os professores que atuam no ES, mas que não contam com titulação adequada para desempenharem suas funções nesse grau de ensino. Tanto que, de acordo com Mendonça (2003), Anísio Teixeira (1900 - 1971), um dos fundadores e primeiro presidente da CAPES, apostava na pós-graduação como o meio mais rápido e eficiente para transformar a universidade brasileira.

Independentemente das motivações da criação e do sucesso do Sistema $\mathrm{CAPES}^{12}$, explicitado nos documentos oficiais e em outros veículos de análise

11 Observe-se que a primeira Lei de Diretrizes e Bases da Educação Nacional, portanto da criação de um instrumento legal para a estrutura e o sistema educacional brasileiro, somente será aprovada em 1961 (lei 4024) e a primeira mudança dessa lei, novamente será no estrato superior, isto é a lei 5540 de 1968, inserindo mudanças na LDB, porém abrangendo apenas a ES. Poucos anos depois é que se vai modificar a lei de Primeiro e Segundo Graus, a Lei 5692, de 1971.

12 O Sistema CAPES de avaliação, agrega a condição de financiamento também, entre suas atribuições, a partir dos primeiros anos da década de 1990, quando passa à condição de Fundação. Sobre histórico da CAPES, além de consultar o próprio Site da Fundação (www.CAPES.gov.br/), cf. Bianchetti (2009). 
e divulgação, o que importa ressaltar aqui é que a iniciativa, novamente é de cima para baixo. Temos na organização e funcionamento da CAPES, o exemplo de uma vigorosa política pública direcionada ao ápice da pirâmide do sistema educacional.

A próxima e atualmente vigente Lei geral da Educação, a mais abrangente que se teve até agora, é a LDBEN de 1996 (Lei 9394). Há nela uma dilatação nos dois extremos no que diz respeito à inclusão ao Sistema educacional de crianças desde o pré-escolar até a pós-graduação, e uma série de meios, muitos ainda não transformados em leis, para garantir que estados e municípios garantam a progressiva e completa universalização da Educação Básica.

Mas talvez uma das mais significativas mudanças no Sistema Educacional Brasileiro, dirigida à Educação Básica, tenha sido, em primeiro lugar, a antecipação do período de escolarização como uma política pública: educação infantil, ampliação dos anos de escolarização etc. e a criação de uma Coordenação de Aperfeiçoamento de Pessoal da Educação Básica, a CAPES da EB, assunto que será objeto de análise e discussão em item posterior.

\subsection{Destacando alguns aspectos da CAPES/ANPEd neste con- texto}

Conforme já apontado, a CAPES, para o ES, é criada em 1951. Porém passam-se cerca de 15 anos, até que efetivamente, no contexto do governo ditatorial pós-1964, seja acionada, receba recursos e passe-se a cobrar dela contribuições na direção da construção do "Brasil potência", via investimentos na melhoria do ensino e da pesquisa, bem como no enfrentamento de outras prioridades no leque de responsabilidades que lhe vão sendo atribuídas a cada novo Plano Nacional de Pós-graduação (PNPG) que é projetado (HOSTINS, 2006).

$\mathrm{Na}$ área de educação, o primeiro curso de pós-graduação stricto sensu, será criado em 1965, na PUC-Rio. De outra parte, para fins deste texto, é importante destacar a criação da Associação Nacional de Pós-graduação e Pesquisa em Educação (ANPEd), no ano de 1978, em grande parte induzida pela CAPES, a fim de esta poder contar com avaliadores e pareceristas ad hoc da área para compor as diversas comissões de que o órgão necessitava para avaliar os programas, projetos, distribuir recursos etc. (FERRARO, 2005).

Naquilo que nos interessa mais diretamente, contudo, destacamos inicialmente o fato de a Associação ter surgido inicialmente como de "Pós-graduação" (PG). A palavra "Pesquisa" será inserida quatro anos após a criação e compõe a sigla "ANPEd" do início da década de 1980 até os dias atuais. Não passa desapercebido aos críticos essa precedência da $\mathrm{PG}$ em relação à pesquisa, bem 
como o fato de a pesquisa ser um atributo da PG. Ferraro e Spósito (2007, p. 1), assim explicitam isto que consideram uma contradição:

ANPEd: Este nome, ao mesmo tempo em que associa entre si as atividades de ensino em nível de pós-graduação e as de pesquisa, encobre e dissimula uma contradição histórica na própria constituição dessa relação. A pesquisa deveria ter antecedido, induzido e fundamentado a pós-graduação. Não foi o que aconteceu no Brasil. Tivemos antes, na maioria das áreas do conhecimento, com destaque para a área da educação, uma pós-graduação que antecedeu a pesquisa: uma pósgraduação pensada e induzida, às vezes apressadamente, na expectativa de que ela pudesse abrir e pavimentar o caminho da pesquisa. A própria ordem dos termos pós-graduação e pesquisa no nome da Associação parece estar denunciando a relação histórica real das duas realidades que respondem pelos nomes de pós-graduação e pesquisa.

Para além deste aspecto questionável em relação às funções clássicas da universidade - ensino, pesquisa e extensão - é imprescindível que se avance para, em um Evento como este, no qual se trata da relação entre PG e EB, compreender como a PG veio relacionando-se com a EB. Quais são os indícios de materialização desta relação?

Se tivermos presente que a CAPES é criada para qualificar os quadros de docentes das universidades, especialmente das públicas e analisando os primeiros anos de atuação do órgão, não há como deixar de perceber que a preocupação precípua é com o ES, com a formação dos professores desse grau. Inclusive há claras induções no sentido, inicialmente, de direcionamento nesta direção e, explicitamente, a partir de meados de 1996, a opção de que, daí por diante, a prioridade seria a "formação de pesquisadores" (KUENZER; MORAES, 2005). Ora, se pensarmos que a PG em educação, volta-se para a formação de professores e de pesquisadores, mesmo que haja preocupações com a $\mathrm{EB}$, o serão de ordem secundária ${ }^{13}$. Isto é, não se forma professores para atuarem na $\mathrm{EB}$ e

13 Não desconhecemos aqui o fato de, com o passar dos anos, mais e mais professores da EB, procurarem, pressionados ou incentivados por protagonismo próprio, fazerem mestrado e doutorado. O que precisa ser aprofundado em termos de pesquisa é a quantidade desses professores, que, concluído seu curso de pós-graduação, permanecem trabalhando na ED ou se evadem para procurar melhores opções de trabalho. Levantamento informal e documental feito na Prefeitura de Florianópolis evidencia que há um incentivo a que seus professores façam a pós-graduação e há retornos, inclusive financeiros, devido a um plano de carreira que contempla vantagens relacionadas à qualificação do corpo docente. Já a realidade da Secretaria de Educação do Estado é diversa, pois nem há incentivos para que os professores façam mestrado e doutorado e no retorno as vantagens são poucas, sendo que uma delas é no próprio processo: a liberação do docente para fazer o curso. Enquanto na Prefeitura há esta opção prevista na legislação e é respeitada, no estado não ocorre o mesmo, levando a que haja evasão do titulado da EB na primeira oportunidade que aparece. De outra parte, a permanência de um mestre ou doutor, seja na Secretaria Municipal, como órgão ou nas escolas do município, cria outro tipo de ambiência, provocando atuações 
quando se faz pesquisa, predomina um tipo de investigação que transforma a escola, os sistemas de ensino, o corpo docente das escolas, suas práticas etc. em 'objetos' de pesquisa. Portanto, predomina, quando voltada à escola, a pesquisa mais de ordem utilitária, sobre a EB e seus agentes e não com ou para eles.

De outra parte, uma varredura nas ementas das disciplinas dos 31 Programas de Pós-graduação da Região Sul, promotores e participantes deste Seminário de Pesquisa onde discutiu-se a relação entre PG e EB, seremos surpreendidos com a pouca menção direta a preocupações com a EB. É evidente que ao não mencionar diretamente não quer dizer que uma linha de pesquisa como "Educação e novas TICs" ou "Trabalho e Educação", não direcionem reflexões e nos programas não se oriente dissertações e teses focalizando a EB. Da mesma forma como não se pode afirmar que a série de ementas de disciplinas como "Educação e infância", "Educação de crianças de 0 a 6 anos", que fazem menção direta, trabalhem ou investiguem com e para a EB. Apenas, neste texto estamos chamando a atenção para que se observe e, quem sabe, sejam assumidos desafios de pesquisar esta questão ${ }^{14}$.

Outro aspecto que a 'varredura', na superficialidade que caracteriza uma leitura de ementas, permite visualizar é que as universidades privadas/comunitárias apresentam disciplinas e ementas vinculadas mais diretamente com as escolas, com os sistemas de ensino, formação de professores para a rede etc., em relação às públicas, desafiando a que se avente a hipótese de que a maior organicidade e proximidade com e das comunidades, por parte destas instituições, as leve a responder a demandas mais imediatas do seu entorno, do que as universidades públicas. Mas, reafirmamos, aqui estão mais desafios e questões para pesquisa do que afirmações, particularmente porque para conclusões mais fundamentadas seriam necessárias pesquisas detalhadas, para além do que o nome de uma disciplina e sua ementa revelam.

Pensamos que valeria a pena também um levantamento cuidadoso a respeito dos Grupos de Trabalho (GTs) da ANPEd e suas temáticas de pesquisa ${ }^{15}$. Um

mais qualificadas e desafiando docentes a procurarem melhorar sua formação via PG.

$14 \mathrm{Na}$ Conferência de abertura da IX ANPEdSUL, Flávia Obino Verle, aprofundou, a partir de dados de sua pesquisa, esta questão da relação entre PG e EB, no contexto dos Programas de Pós-graduação em Educação, com base nas temáticas e ações dos grupos e das linhas de pesquisa dos Programas.

15 Aguiar (2007) escreve um texto relacionado a esta temática, com o significativo título: "ANPEd e Educação Básica: Contribuições para a política educacional no Brasil". Segundo a autora: "No início da presente década, mediante a produção científica dos grupos de trabalho e grupos de estudo que a constituem e de uma permanente atuação crítica e propositiva, a ANPEd tem ampliado a sua contribuição no campo da educação básica, particularmente no que toca às questões das políticas públicas traduzidas nos programas governamentais dirigidos aos sistemas de ensino" (p. 01). E mais para o final do texto, em uma de suas conclusões, afirma, referindo-se à realização do "1º Simpósio Nacional de Educação Básica", em 2006, que este "evidenciou, também, no tocante às políticas atuais, os embates em torno do financiamento da educação e a emergência da proposta de criação do FUNDEB, como uma possibilidade 
olhar superficial, no estilo primeira varredura, mostra que, entre os 23 GTs, a preocupação direta, focalizada, explícita com a EB, pode ser encontrado em apenas três (3) GTs: "Educação da criança de 0 a 6 anos" (GT 07); "Alfabetização, Leitura e Escrita" (GT 10) e "Educação Fundamental" (GT 13). Evidentemente que referências indiretas às preocupações com a EB podem ser encontradas em GTs como: "Formação de professores" (GT 08), "Estado e política educacional" (GT 05), "Psicologia da Educação" (GT 20) e outros. No entanto, da mesma forma que apontamos acima em relação a disciplinas e ementas dos Programas, seria imprescindível examinar detidamente o que é apresentado e discutido nas Reuniões Anuais (RA), no interior dos GTs a fim de distinguir o que é pesquisar sobre, bem como o com e o para quem. O que é inegável, contudo, é que a CAPES que induz e a ANPEd que congrega os pesquisadores para as discussões nas RAs, têm como horizonte a pesquisa, enquanto na EB, em função das condições em que os sistemas funcionam, demandam mais o ensino e a aplicação.

E é neste último aspecto que consideramos importante que se dedique tempo e reflexão à questão da organização e funcionamento da CAPES para a Educação Básica.

\section{UMA CAPES PARA A EDUCAÇÃO BÁSICA: UMA INICIATIVA TARDIA E INSUFICIENTE}

"Com o passar do tempo e com o fortalecimento da concepção de que a carreira e o desempenho profissional são patrimônios de alto valor e quesitos imprescindiveis para a garantia da qualidade social da educação, este quadro começou a mudar. Passo a passo a responsabilidade pela formação está

sendo deslocada da iniciativa individual para o contexto das politicas públicas, transformando-se em compromisso com um projeto social de Nação, capaz de contribuir para uma sociedade soberana e justa”.

[(Excerto de texto dos membros do CTC-EB/ CAPES,Mandato 2008 -2010)]

Em 11 de fevereiro de 2008, poucos dias após a aprovação do Estatuto da Nova CAPES, o então Ministro Fernando Haddad declarava que "não é admissí-

para o redimensionamento do financiamento das diversas etapas e modalidades da educação básica" (p. 15). 
vel que um país que atingiu o $15^{\circ}$ lugar no ranking de produção científica mundial, esteja em $50^{\circ}$ lugar na qualidade da educação básica" ${ }^{16}$. O que o Ministro estava a dizer é que, considerando-se os resultados dos estudantes brasileiros no Program of International Student Assessment (PISA) e considerando-se a expressiva quantidade das publicações científicas de nossos mestres e doutores, os dois níveis da educação brasileira viviam inadmissivelmente apartados, em mundos muito distintos, observando-se, na PG, um desempenho louvável e, na $\mathrm{EB}$, um desempenho sofrível ou, mesmo, pífio.

Alguns meses mais tarde, em 8 de julho de 2008, com a Nova CAPES já ensaiando as suas primeiras ações, o Ministro foi ainda mais direto quando declarou: "Nossa grande tarefa, agora, é traduzir esse acúmulo de conhecimento para a área do magistério, formando professores para a educação básica." ${ }^{17}$ $\mathrm{O}$ Ministro referia-se à necessidade de colocar o acúmulo de experiência $\mathrm{e}$ conhecimento da CAPES, no âmbito da formação de Mestres e Doutores, ou seja, na formação de professores para a ES, a serviço da formação de professores para a EB.

A idéia de criação de uma Nova CAPES foi materializada pela Lei n. 11.502, de 11 de julho de 2007, que modifica as competências e a estrutura organizacional da CAPES, cria o Conselho Técnico-científico da Educação Básica (CTCEB) e autoriza a concessão de bolsas de estudos e de pesquisa a participantes de programas de formação inicial e continuada de professores para a EB. Trata-se de uma mudança fundamental no papel historicamente desenvolvido por esta Instituição. Concretamente, a lei estabelece como missão da CAPES induzir e fomentar a formação inicial e continuada de profissionais do magistério. A lei destaca ainda o papel da CAPES na valorização do magistério em todos os níveis e que a formação inicial se daria preferencialmente na modalidade presencial, e a formação continuada, preferencialmente, a distância. Daí a explicação para a criação de duas Diretorias voltadas para as questões da EB na CAPES - a Diretoria de Educação Básica Presencial e a Diretoria de Educação a Distância.

A lei, envolvendo a CAPES na formação de professores para a EB, só se transformaria em realidade com o Decreto Presidencial de 20 de dezembro de 2007 e teve alguns antecedentes dignos de nota, entre os quais destacam-se:

1. O Plano de Desenvolvimento da Educação (PDE) - divulgado em março de 2007 e publicado em 24 de abril de 2007;

16 Declaração do Ministro Fernando Haddad, no Ministério da Educação, em Brasília, diante dos 45 coordenadores de área da CAPES que tomaram posse naquele dia.

17 Declaração do Ministro da Educação, em Brasília, por ocasião da divulgação dos dados da produção científica brasileira, anunciada como sendo a $15^{\mathrm{a}}$ no ranking internacional. 
2. O Plano de Metas Compromisso Todos pela Educação: Decreto n. 6.094 (24 de abril de 2007) que, entre outras, cria o Índice de Desenvolvimento da Educação Básica (IDEB);

3. O Relatório de Conselheiros do Conselho Nacional de Educação (CNE) sobre o Apagão Educacional (publicado em maio de 2007);

4. O Diagnóstico das Licenciaturas e as demandas da Educação Básica - Estudo realizado pela DEAES/INEP, em 2007;

A estas ações seguiram-se duas que tornaram a Nova CAPES uma realidade:

1. O Decreto n. 6.316 de 20 de dezembro de 2007, que aprova o Estatuto da Nova CAPES;

2. A instalação da primeira Diretoria de Educação Básica Presencial da Nova CAPES, em Janeiro de 2008.

Todas estas ações tiveram relação direta com a criação da Nova CAPES e, por fazerem parte de um conjunto de preocupações e medidas, merecem ser, mesmo que rapidamente, contextualizadas e discutidas.

O PDE, consubstanciado em documento de 43 páginas, publicado pelo MEC, adquire importância não só por ser, como bem destacou Saviani (2007b, p. 1233), "um grande guarda-chuva que abriga praticamente todos os programas em desenvolvimento pelo MEC", mas também pelo fato de o conjunto de suas ações estarem voltadas para a EB e, por isso mesmo, definirem as diretrizes das novas Diretorias, demandando (1) o estabelecimento de metas, o seu constante monitoramento, o estímulo, o fomento, a avaliação e a responsabilização como instrumentos necessários para superar as fragilidades da educação brasileira e (2) que a educação passasse a ser vista no seu todo, superando falsas oposições como as que apartavam a ES da EB, a PG da graduação, o ensino médio da educação profissional, o campus da escola. Fica, portanto, evidente que a Nova CAPES surge motivada pela percepção de que a baixa qualidade da EB resulta em grande parte do histórico apartheid educacional instalado no país, que o PDE buscava corrigir mediante todo um conjunto de ações.

Importante lembrar que já constava do PDE a criação dos Institutos Federais de Educação Tecnológica (IFETs). A sua missão, entre outras, era "oferecer programas especiais de formação pedagógica inicial e continuada, com vistas à formação de professores para a educação básica, sobretudo nas áreas de física, química, biologia e matemática, de acordo com as demandas de âmbito local e 
regional" (PDE, 2007). Estes Institutos foram criados pelo Decreto n. 6.095/07, a partir da transformação dos Centros Federais de Educação Tecnológica (CEFETs) existentes, dando a estes a nova atribuição de formar professores para a educação profissional e tecnológica, mais especificamente, de formar professores nas áreas identificadas à época como as mais carentes.

Da mesma forma, o "Plano de Metas Compromisso Todos pela Educação", que estabelece profundos compromissos de busca de qualidade entre a União, os estados, e os municípios, adquire grande importância pelos mecanismos de monitoramento definidos e, em especial, pela criação do Índice de Desenvolvimento da Educação Básica (IDEB), que coloca cada estado, município e escola diante de metas específicas. Questionáveis ou não, estas metas geraram num primeiro momento, e continuam a gerar ainda hoje, mobilização de lideranças e gestores educacionais, despertando atenção especialmente para a organização curricular, implicitamente definida pela Prova Brasil e pelo Sistema Nacional de Avaliação da Educação Básica (SAEB). Com a quase totalidade dos estados tendo, ao final, assinado o Compromisso, ficou evidenciado que um novo esforço nacional pela qualidade da EB estava a caminho. Se será bem sucedido ou não só o tempo dirá, mas a verdade é que as escolas do país e os Secretários de Educação dos estados e municípios estão hoje atentos para as diretrizes da Prova Brasil e do SAEB e, consequentemente, para o IDEB e suas implicações sobre o financiamento de suas ações específicas.

O Relatório do Conselho Nacional de Educação (CNE) sobre o apagão educacional, publicado em maio de 2007, com a chancela do ex-ministro Murílio Hingel e dos ex-reitores Mozart Neves Ramos e Antonio Ibañez Ruiz, a partir de dados do Instituto Nacional de Estudos e Pesquisas Educacionais Anísio Teixeira (INEP), teve ampla repercussão na grande mídia (cf. editorial do Estado de São Paulo, de 08 de julho de 2007). O Relatório declarava a existência de um apagão educacional no ensino básico brasileiro, mostrando uma carência de 246 mil professores formados em física, química, biologia e matemática (RUIZ et al, 2007). O Ministro Haddad imediatamente encomendou a uma Comissão, constituída por representantes das várias secretarias do MEC e de várias diretorias do INEP, um estudo para verificar a veracidade dessas constatações. A Comissão, com dificuldades para se reunir, não chegou a produzir um relatório, mas o Diretor de Estatísticas e Avaliação da ES do INEP, com os dados em mãos, entregou ao Ministro um relatório de 28 páginas intitulado "As Licenciaturas e o Ensino Básico Brasileiro: Diagnóstico"18. O texto basicamente corroborava

18 Este texto, produzido por Dilvo Ristoff, em 2007, na qualidade de Diretor de Estatísticas e Avaliação da ES do INEP, teve ampla circulação, mas só veio a ser publicado na íntegra recentemente. Cf. Ristoff (2011). 
a carência de licenciados em algumas das áreas apontadas pelos Conselheiros do $\mathrm{CNE}$, mas as suas constatações revelaram ainda outros dados que mereciam atenção especial dos formuladores de políticas e gestores, quais sejam:

1. havia mais professores atuantes em todas as disciplinas da educação básica do que a demanda hipotética projetada para o seu atendimento [(havia 323.109 docentes em exercício a mais do que a demanda estimada para o ensino fundamental ( 5 à $8^{a}$ Séries) e médio, o que equivalia a uma oferta de docentes $44,5 \%$ acima da demanda)];

2. nos últimos cinco anos (2001 a 2005), o número de ingressantes e de concluintes, em todas as licenciaturas, mostrava crescimento todos os anos;

3. em todas as disciplinas, exceto em Física e Química, havia mais professores licenciados nos últimos 25 anos do que a demanda hipotética projetada para o atendimento das necessidades do ensino médio e fundamental de $5^{\text {a }}$. a $8^{\text {a }}$. Série;

4. em Física e Química, mesmo que todos os licenciados nos últimos 25 anos exercessem a profissão de professor do ensino médio, seria impossível atender à demanda hipotética para o atendimento destas disciplinas; Em Física, a demanda hipotética era aproximadamente três vezes superior ao número de licenciados nos últimos 25 anos e, em Química, mais de duas vezes;

5. em todas as áreas, inclusive em Física e Química, o número de licenciados é consideravelmente maior do que o número de professores licenciados atuantes, indicando forte evasão profissional apesar da grande disponibilidade de postos de trabalho.

Este relatório não só subsidiou as reuniões do Ministro com a Câmara de $\mathrm{EB}$ e do CNE, mas foi peça importante para a formulação do plano de envolvimento da CAPES num ambicioso programa de formação de professores. Alguns meses mais tarde, no final daquele ano, o plano estava elaborado e transformado em Decreto. Embora, legalmente, como já destacamos, a Nova CAPES tenha passado a existir a partir da Lei n. 11.502, de 11 de julho de 2007, a viabilidade de sua existência passa a vigorar a partir de 20 de dezembro, quando foi assinado o Decreto n. $6.316^{19}$. Dadas estas condições a Nova CAPES instala-se efetivamente a partir de meados de janeiro de 2008.

19 Decreto recentemente modificado pelo Decreto n. 7.692, de 02 de março de 2012. 
As resistências à Nova CAPES, também jocosamente chamada de "CAPES do B", vinham de alguns setores da sociedade, do próprio governo e, de modo especial da Academia e da burocracia interna à CAPES. As críticas são de diversas naturezas, que vão desde a rejeição ao uso puro e simples da modalidade a distância para a formação de professores ${ }^{20}$, à polarização supostamente ingênua entre as duas modalidades ${ }^{21}$, à criação de um modelo conteudista e paralelo de formação de professores, como no caso dos IFETS ${ }^{22}$ - instituições vistas por muitos como sem tradição e sem preparo para a tarefa - à aplicação de um modelo avaliativo produtivista como o aplicado aos cursos de PG stricto $s \operatorname{sus}^{23}$, até o temor de que a história da CAPES, no âmbito de sua atuação exitosa, reconhecida e consagrada na $\mathrm{PG}$, nacional e internacionalmente, fosse posta a perder. Subjacente sempre estava o temor de que, com a ampliação de suas atribuições, a CAPES da PG perdesse recursos, tendo que dividi-los com a CAPES da EB, ficando a instituição sob a pressão cada vez maior de seus novos e, para a burocracia da CAPES, desconhecidos interlocutores ${ }^{24}$. Para aplacar esta preocupação, o Ministro da Educação deixou claro, desde o início, que o orçamento da CAPES sofreria alterações profundas. Mesmo antes de a Nova CAPES estar criada, o Ministro informou ao Conselho Superior da CAPES que "o orçamento da CAPES vai mais que dobrar em quatro anos. Só para 2008, a proposta orçamentária prevê investimentos de $\mathrm{R} \$ 1,3$ bilhão. E mais $\mathrm{R} \$ 8$ milhões para a construção da nova sede" 25 .

20 Cabe destacar que, embora a lei estabeleça a preferencialidade da educação presencial para a formação inicial e a primazia da educação a distância para a formação de professores atuantes na rede, o próprio Ministro, em suas declarações em 4 de dezembro de 2007, ao falar aos conselheiros do Conselho Superior da CAPES, dá margem à interpretação diversa: "A formação continuada dos professores poderá ser feita a distância. Em alguns casos, até a formação inicial, disse Haddad". (Informativo da CAPES de terça-feira, 04 de dezembro de 2007, 21h).

21 "Carece de argumentos epistemológicos e teóricos a divisão da formação de professores nas modalidades presencial e a distância, como diretriz para definição das políticas nacionais." (Editorial de Educação \& Sociedade, Campinas, CEDES, v. 29 n. 105, p. 10, set./dez. 2008)

22 A oferta de cursos e programas de ES a distância por instituições públicas de ensino superior, em articulação com pólos de apoio presencial, nos municípios, representa, sem dúvida, ruptura com os programas de formação a distância, de curta duração, de caráter mercadológico, que perduraram até pouco tempo em nosso país. Esta iniciativa, no entanto, tem suas contradições, na medida em que privilegia a modalidade de educação à distância para a formação inicial de professores em exercício (FREITAS, 2007).

23 A transposição da lógica da PG às escolas de EB submetem esta e seus profissionais à lógica produtivista que hoje caracteriza a PG em nosso país. Uma política com esta feição institui a competitividade entre as IES, mediante processos de creditação de instituições formadoras, e ainda a competitividade entre os professores da EB, pelos cursos de PG, que não estarão disponíveis a todos os professores, mas aos mais "qualificados" (FREITAS, 2007).

24 Entre eles: Prefeitos, secretários municipais, secretários estaduais de educação, União Nacional dos Conselhos Municipais de Educação (UNCME), União Nacional dos Dirigentes Municipais de Educação (UNDIME) e governadores dos estados

25 Informativo da CAPES de 4 de dezembro de 2007. 
E, efetivamente, o orçamento da CAPES teve aumento significativo nos anos seguintes, chegando, em 2012, a cerca 3.5 bilhões de reais. Ainda em 2008, instala-se a Diretoria de Educação Básica Presencial; a Diretoria de Educação a Distância, abrigando a Universidade Aberta do Brasil (UAB); o Conselho Técnico-Científico da EB e, após aproximadamente um ano de debates, cria-se a política nacional de formação de professores para a EB. A política, que, entre outras, disciplina a atuação da CAPES no fomento a programas de formação inicial e continuada, foi instituída pelo Decreto n. 6.755 de 29 de janeiro de 2009.

Tendo como princípios norteadores, entre outros, o compromisso público do Estado com a formação docente para todas as etapas da EB, buscando a colaboração de todos os entes federados com a idéia de que a formação docente faz parte de um projeto social e ético que contribua para a consolidação de uma nação soberana, democrática, justa, inclusiva e que promova a emancipação dos indivíduos e grupos sociais, foram definidos dez objetivos da "Política Nacional de Formação de Profissionais do Magistério da EB" (Cf. Decreto n. 6.755/2009).

Para alcançar os objetivos formulados, foram criados os Fóruns Estaduais Permanentes de Apoio à Formação Docente, em regime de colaboração entre a União, os Estados, o Distrito Federal e os Municípios, e por meio de ações e programas específicos do MEC.

A partir dos dados gerados pelo Censo da EB do INEP, cada unidade da federação ficou responsável pela formulação do Plano Estratégico, visando alcançar os objetivos especificados no art. $5^{\circ}$ do Decreto acima mencionado.

Percebe-se, portanto, uma grande preocupação com as necessidades de formação de profissionais do magistério em cada uma das unidades da federação para atender a demanda das escolas vis- $a$-vis a capacidade de formação das IES públicas. Os cursos de formação inicial e continuada a serem oferecidos não seriam mais, portanto, expressão de desejos de instituições, mas fruto de uma ação articulada em cada estado e no Distrito Federal, coordenado e monitorado pelo respectivo Fórum Permanente.

\subsection{Esboços de avaliação da Nova CAPES}

Não cabe aqui uma análise aprofundada de cada uma das metas, mas é importante, três anos após a implantação da Política de Formação dos Profissionais do Magistério da Nova CAPES, verificar até que ponto os grandes objetivos foram efetivamente alcançados e, se não foram, se o comportamento dos diferentes níveis educacionais sugere que o Brasil está no caminho certo e que, portanto, terá condições de viabilizar a política implantada. 
Antes, no entanto, convém destacar que, no âmbito das Diretorias da CAPES, do Conselho Técnico-Científico da EB, da Secretaria de Educação a Distância, da Secretaria de EB, de ES, de Educação Tecnológica e do MEC como um todo havia, à época da implantação da referida Política, também a compreensão, de que as ações, em grande parte, teriam que ser desenvolvidas em regime de estreita cooperação e de parceria intensa com as universidades públicas, as Secretarias Estaduais e Municipais de Educação, além de necessitar do apoio das entidades acadêmicas e políticas representativas das diversas licenciaturas. A composição dos Fóruns permanentes reflete claramente esta preocupação.

Para que estas ações estivessem em sintonia com a idéia do pacto federativo e com a visão sistêmica da educação propostas pelo PDE havia que se assegurar que, por ocasião da formulação da Política in casu, elas fossem cuidadosamente cotejadas para evitar duplicidade de esforços e a pulverização de recursos humanos e materiais. Em especial havia que se dar total atenção ao risco de que um grande número de ações, a menos que articuladas e integradas em torno de metas quantitativas e qualitativas, retirasse a centralidade que a carência de docentes licenciados atuantes na EB impunha a todo o sistema educacional e a toda a sociedade.

Os pressupostos que nortearam, por exemplo, a elaboração do planejamento para a recém-criada Diretoria de EB Presencial da CAPES tiveram o seguinte teor:

1. As ações em torno da EB devem estar ancoradas na afirmação da imagem de futuro que temos para o Brasil e que está presente na LDBEN, no PNE, no PDE e outros instrumentos legais, qual seja: um país soberano, dono de seu destino; um país avançado nas artes, na ciência e na tecnologia; um país justo e inclusivo, que promova a emancipação de grupos sociais e indivíduos para que estes, com a educação de qualidade a quem têm direito, possam ajudar a gerar as suas próprias oportunidades de mobilidade social.

2. As ações com relação à EB, de uma maneira ou outra, atingirão a todos os setores da sociedade: a indústria, o comércio, a agricultura, os serviços e a qualidade da vida de todos os brasileiros.

3. As ações em torno da EB devem ser abordadas e definidas, concomitantemente, em três frentes: política, administrativa e acadêmica.

4. O sucesso das decisões, com relação à política de formação de professores para a EB, dependerá do engajamento dos profissionais da 
educação e do envolvimento de todos os cidadãos brasileiros, políticos, pais, professores, jovens, adultos, a sociedade como um todo.

Como conseqüência, as linhas de ação e as ações propriamente ditas tinham que estar sustentadas nas constatações feitas, quais sejam, a grande carência de docentes licenciados atuantes nas disciplinas específicas de atendimento à $\mathrm{EB}$, revelando que as disciplinas de EB estão em grande parte sendo ministradas por professores improvisados, professores cuja formação inicial não é de licenciatura nas disciplinas que ministram; os altos índices de evasão profissional dos professores licenciados, apesar da grande disponibilidade de postos de trabalho; a carência de licenciados em Física e Química, exigindo por parte do estado tratamento emergencial à formação de professores nestas duas áreas do conhecimento; a deficiente formação de professores nos campi de nossas universidades e IES, especialmente no tocante à aproximação entre teoria e prática pedagógica; as persistentes contradições, incongruências e incompatibilidades entre os currículos, os projetos pedagógicos dos cursos de licenciatura e a formação específica de docentes para a EB; o apartheid que distancia a universidade da escola e a PG da graduação e da EB; o baixo $\theta$ desempenho dos estudantes brasileiros nos exames nacionais e internacionais; e os muitos ambientes escolares incompatíveis com o processo de ensino-aprendizagem de qualidade, prejudicando sobremaneira a auto-estima de docentes e estudantes.

Diante das constatações acima, a Diretoria de Educação Básica Presencial apresentou, durante a Conferência Nacional da Educação Básica em 2008, as linhas de ação a seguir como objetivos básicos a serem alcançados, em prazos a serem definidos caso a caso, conforme permitissem os recursos financeiros e as condições estruturais dos sistemas educacionais:

1. todas as disciplinas da EB terão professores licenciados para ministrálas;

2. nenhuma evasão profissional de licenciados deve encontrar justificativa na falta de valorização do magistério;

3. todos os professores licenciados deverão ter formação prática em sala de aula ao longo do curso;

4. todos os licenciados serão formados em cursos com currículos especialmente construídos para a formação de docentes para a EB;

5. todos os níveis de escolaridade, desde a PG stricto sensu à EB, participarão do esforço nacional comum de melhoria da qualidade da educação brasileira e da formação docente de forma integrada e comprometida; 
6. os estudantes da EB deverão demonstrar melhora constante dos níveis de desempenho nos exames nacionais e internacionais;

7. todas as escolas brasileiras deverão apresentar atmosfera propícia para o estudo, o conseqüente avanço cognitivo dos estudantes e convívio social harmonioso.

A proposta da Diretoria da CAPES, como se pode concluir, antecipa as linhas gerais da Política de Formação dos Profissionais do Magistério, materializada no Decreto de 2009. Passados quatro anos da implantação da Nova CAPES, entendemos que cabe verificar se a política implantada logrou atingir os resultados esperados.

O Livro Azul (2010), produzido a partir da $4^{\mathrm{a}}$. Conferência Nacional de Ciência, Tecnologia e Inovação para o Desenvolvimento Sustentável, realizada em 2010, destaca que para atingir novos patamares de desenvolvimento o Brasil necessita hoje de

uma revolução na educação, em todos os níveis [pois] a baixa escolaridade da população brasileira constitui importante obstáculo ao desenvolvimento científico e tecnológico do País. Os grandes projetos previstos para a próxima década, nas áreas de petróleo, bioenergias, saúde, tecnologias de informação e comunicação, exploração sustentável dos biomas, entre outros, requerem um grande número de profissionais bem-qualificados nos níveis técnico e superior. $\mathrm{E}$ a formação desse contingente pressupõe uma EB de qualidade para todos os brasileiros (2010, p. 99).

Ao destacar que a universalização do ensino fundamental, acompanhada de sua municipalização, não se fez acompanhar nem da desejada melhoria na qualidade do ensino nem da melhoria da inclusão no ensino médio ou da redução dos altos índices de evasão, tendo, ao contrário, levado a uma desvalorização do professor, a uma pauperização generalizada das condições de infra-estrutura das escolas de $\mathrm{EB}$, a uma redução da carga horária escolar, e a uma maior desarticulação em torno de um projeto nacional, o documento aponta que medidas recentes, como a criação do PDE, a implantação do piso salarial nacional, a transferência da coordenação da formação para a CAPES, com a criação de programas de apoio à formação inicial de professores leigos e de formação continuada para professores atuantes na rede pública começam a mostrar resultados positivos:

Iniciativas recentes ajudam a mudar esse quadro, levando à consolidação de uma política nacional para essa matéria. O Plano Nacional 
de Formação de Professores da Educação Básica, instituído em 2009, articula ações em vários níveis para ministrar cursos superiores gratuitos e de qualidade a professores sem formação adequada em exercício das escolas públicas, atribuindo à CAPES a indução, o fomento e a avaliação desses cursos. O piso salarial nacional, recentemente proposto pelo MEC e aprovado pelo Congresso, e as bolsas de estudo para cursos de licenciatura, fornecidas pela CAPES, levaram a um aumento das matrículas nesses cursos. Essas iniciativas precisam ser ampliadas e aprofundadas no período 2010-2020, de modo a compensar décadas de negligência nessa área (Livro Azul, 2010, p. 97).

As medidas adotadas pelo MEC, desde a criação da Nova CAPES, pretendem ser sinalizadores sobre os caminhos a serem seguidos para a melhoria da EB, reduzindo o improviso, melhorando a formação de docentes e aproximando a PG da graduação. Para que se possa confirmar se esta sinalização é forte e visível na comunidade acadêmica e na sociedade brasileira há que se olhar para os projetos criados no âmbito das novas políticas para as licenciaturas: Programa Institucional de Bolsas de Iniciação à Docência (PIBID), Observatório da Educação, Pró-docência etc. e para os dados do Censo da EB e Superior. Só assim poderemos verificar se efetivamente ocorreram os avanços esperados.

\subsection{O potencial dos Programas criados}

A boa receptividade de um Programa como o PIBID, por exemplo, já desde o primeiro momento, prometia impactos positivos, não só pelos eventuais resultados específicos esperados, mas pelo próprio processo de sua implantação. Por um lado, o PIBID possibilitou que, pela primeira vez na história do país, a CAPES concedesse, em um mesmo projeto, bolsas para alunos de doutorado, mestrado, professores de PG e graduação, estudantes de licenciatura e professores atuantes na escola, abrindo canais de comunicação historicamente fechados. Revelou, igualmente, a grande dificuldade de a universidade pública voltar-se para a escola pública e de dialogar com os responsáveis estaduais e municipais e pelos gestores da EB. As dificuldades observadas em vários estados para cumprir a exigência da CAPES da existência de um convênio de cooperação entre universidades, secretarias e escolas, são a demonstração emblemática do apartheid existente entre os diferentes níveis de ensino. Apesar dos altos investimentos de um programa desta natureza, no entanto, buscando aproximar teoria e prática, dando ao licenciando oportunidades reais de estágio ao longo do seu curso, permitindo que ele conheça o seu futuro locus de atuação, dando aos professores das licenciaturas um quadro mais preciso da 
realidade da escola e aos pesquisadores uma oportunidade de considerar novas pertinências na definição de suas linhas de pesquisa, apesar de tudo isso, e apesar dos muitos projetos interessantes que foram submetidos à CAPES nos últimos anos, é evidente que um programa como o PIBID não tem nem a capacidade nem a pretensão de ser um solucionador dos inúmeros problemas da EB. É, no entanto, um sinalizador importante dos rumos que devem ser seguidos por professores das universidades, professores das escolas, alunos de graduação e $\mathrm{PG}$, programas e dirigentes dos vários níveis educacionais.

O seu alcance, no entanto, como mostra o quadro abaixo, é extremamente limitado:

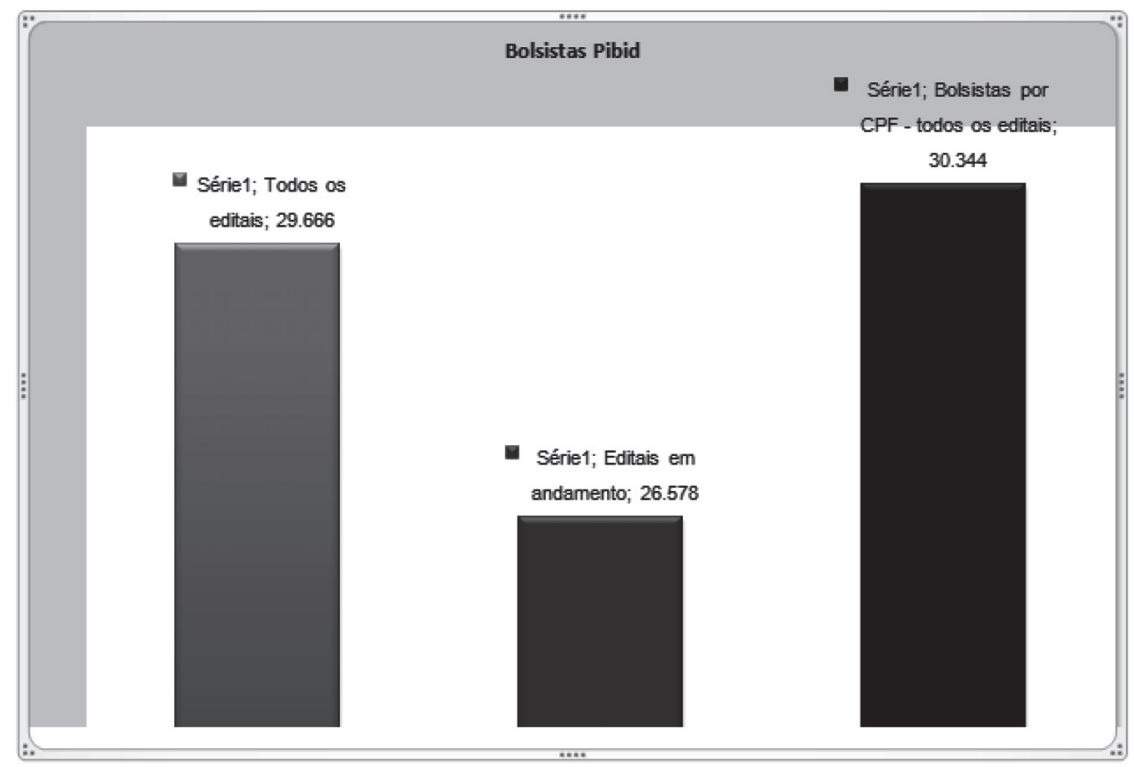

Fonte: CAPES/MEC - Diretoria de Educação Básica Presencial

Atingindo cerca de 30.000 bolsistas em três anos, envolvendo professores e estudantes de todos os níveis educacionais é decididamente um dado inexpressivo dentro de um universo que mobiliza milhões de pessoas e que apresenta altas taxas de evasão profissional.

Da mesma forma, o Pró-docência. Se o PIBID tem como objetivo principalmente o rompimento do apartheid inter-institucional e a aproximação dos diferentes níveis de ensino e agentes educacionais, o Pró-docência tem na, sua origem, a preocupação com a organização curricular, buscando uma melhor articulação entre o que estabelecem as Diretrizes Curriculares Nacionais, os 
Projetos Pedagógicos de Curso no âmbito das Licenciaturas, os programas de disciplinas nos cursos de licenciatura e os projetos político-pedagógicos das escolas. Por tratar-se de um programa, em comparação com o PIBID, pequeno e com poucos recursos, o seu mérito está mais na indução de comportamentos pontuais do que na solução dos grandes problemas da formação de professores.

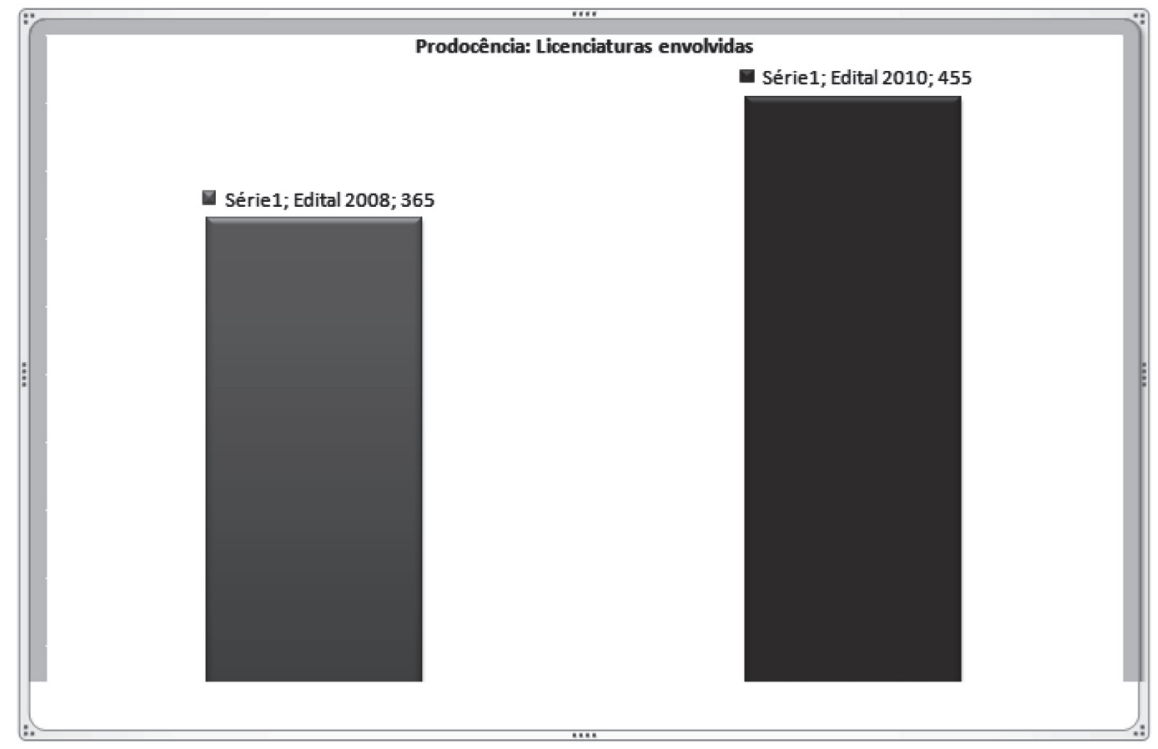

Fonte: CAPES/MEC - Diretoria de Educação Básica Presencial

Cabe ainda destacar um terceiro Programa da Nova CAPES, que tem como uma preocupação importante o rompimento do apartheid entre graduação e PG e aproximação da pesquisa com as licenciaturas. Trata-se do Programa Observatório da Educação - um programa criado em parceria com o INEP. Este programa surgiu da percepção da importância e da necessidade de democratizar o acesso aos dados da EB e superior disponíveis no INEP, como elementos de pesquisa e como suporte decisivo para a orientação das políticas educacionais do país. Embora o Programa tenha sido criado antes da própria implantação das novas Diretorias da CAPES, a transferência de sua gestão para a Diretoria de Educação Básica Presencial sinalizou o interesse do MEC em promover pesquisas no âmbito das licenciaturas e na sua relação com a EB, como pode ser amplamente verificado nos editais do Programa. 


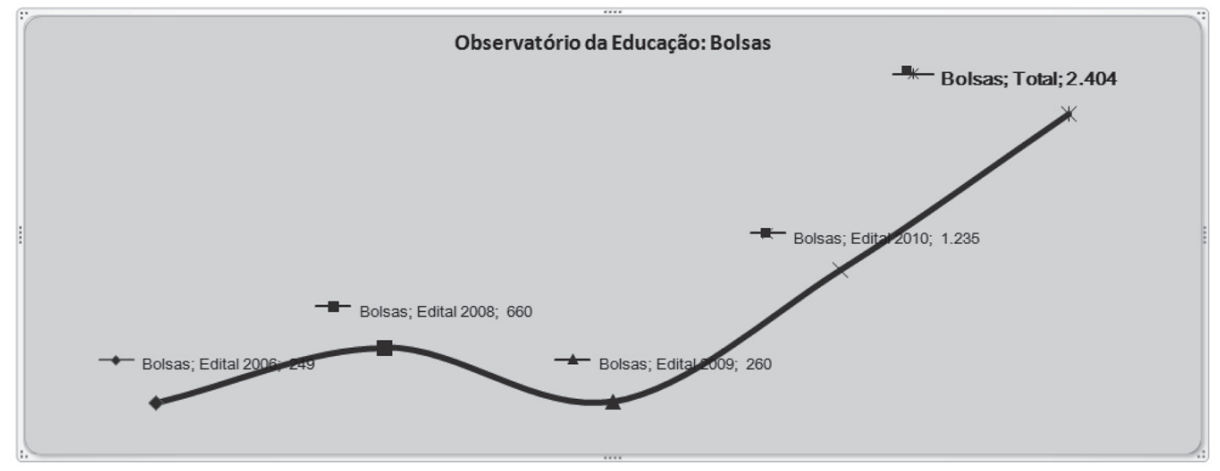

Fonte: CAPES/MEC - Diretoria de Educação Básica Presencial

Determinada a aproximar a PG da graduação e das escolas do país - ou a criar um "circulo virtuoso", como diria Cury (2004) - a CAPES mobilizou grandes esforços no sentido de promover a formação de professores em quantidade suficiente e qualidade adequada, buscando atender o que exige a legislação brasileira. Estes esforços vêm sendo empreendidos, juntamente com os Fóruns Permanentes, no âmbito da política nacional de formação, presencialmente e através da UAB, que tem forte atuação na formação de professores. O principal programa neste contexto é o Plano Nacional de Formação dos Professores da Educação Básica (PARFOR), programa da CAPES em regime de colaboração com as Secretarias de Educação dos Estados, do Distrito Federal e dos Municípios e com as IES, envolvendo oferecimento de primeira licenciatura, segunda licenciatura e formação pedagógica aos não licenciados em exercício na rede pública.

Para que se possa melhor dimensionar o impacto deste programa há que se observar rapidamente a demanda hipotética de professores para os sistemas estaduais e municipais e o comportamento das matrículas nas licenciaturas nos últimos anos, em especial desde a implantação da Nova CAPES.

Dados do Censo da ES de 2010 informam que, embora o número total de concluintes da ES tenha crescido nos últimos dois anos, o mesmo não pode ser dito das licenciaturas, revertendo-se, portanto, a tendência apontada no estudo do INEP de 2007. O gráfico a seguir revela esta nova tendência nas licenciaturas do país, em contraste com o crescimento do número de bacharéis e de tecnólogos: 


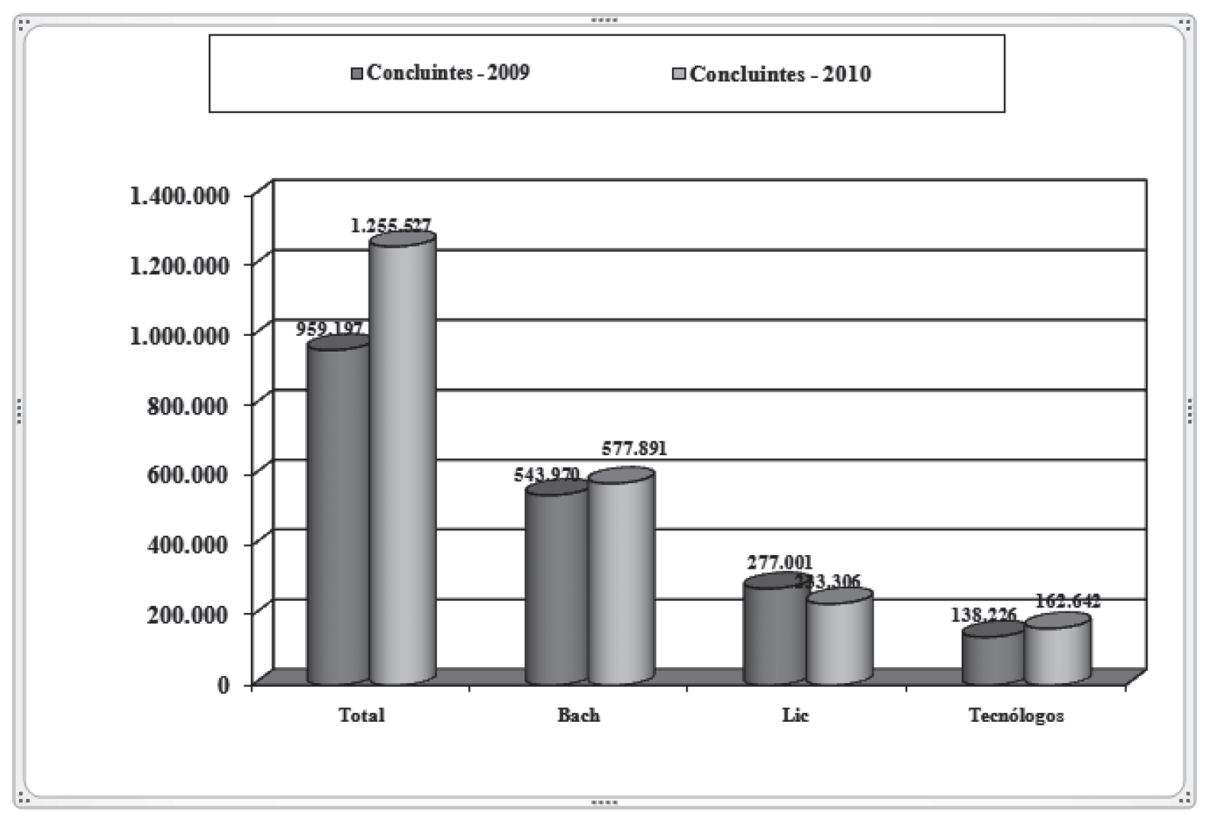

Fonte: INEP/MEC - Censo da ES 2009-2010

Percebe-se, portanto, que o crescimento do sistema, tanto em termos de matrículas como de concluintes, não se traduziu para as licenciaturas. Cabe ainda destacar que um número nada desprezível de concluintes das licenciaturas gradua-se simultaneamente como bacharel (com titulação dupla) e que, fôssemos computar os concluintes de licenciatura por modalidade (presencial ou a distância), teríamos uma diminuição de concluintes em ambas as modalidades, indicando, salvo melhor juízo, que há uma diminuição de interesse por esses cursos e pelo que eles formam. Em outras palavras, diminui a procura pela profissão de professor, enquanto crescem os concluintes tecnólogos e bacharéis.

Tal constatação sustenta-se também na observação do comportamento histórico das matrículas nas licenciaturas. Enquanto as matrículas globais na ES têm aumentado nos últimos anos, tendo crescido $6,5 \%$ só no ano 2009 2010, as matrículas nas licenciaturas vêm diminuindo constantemente desde 2005, como mostra o gráfico a seguir: 


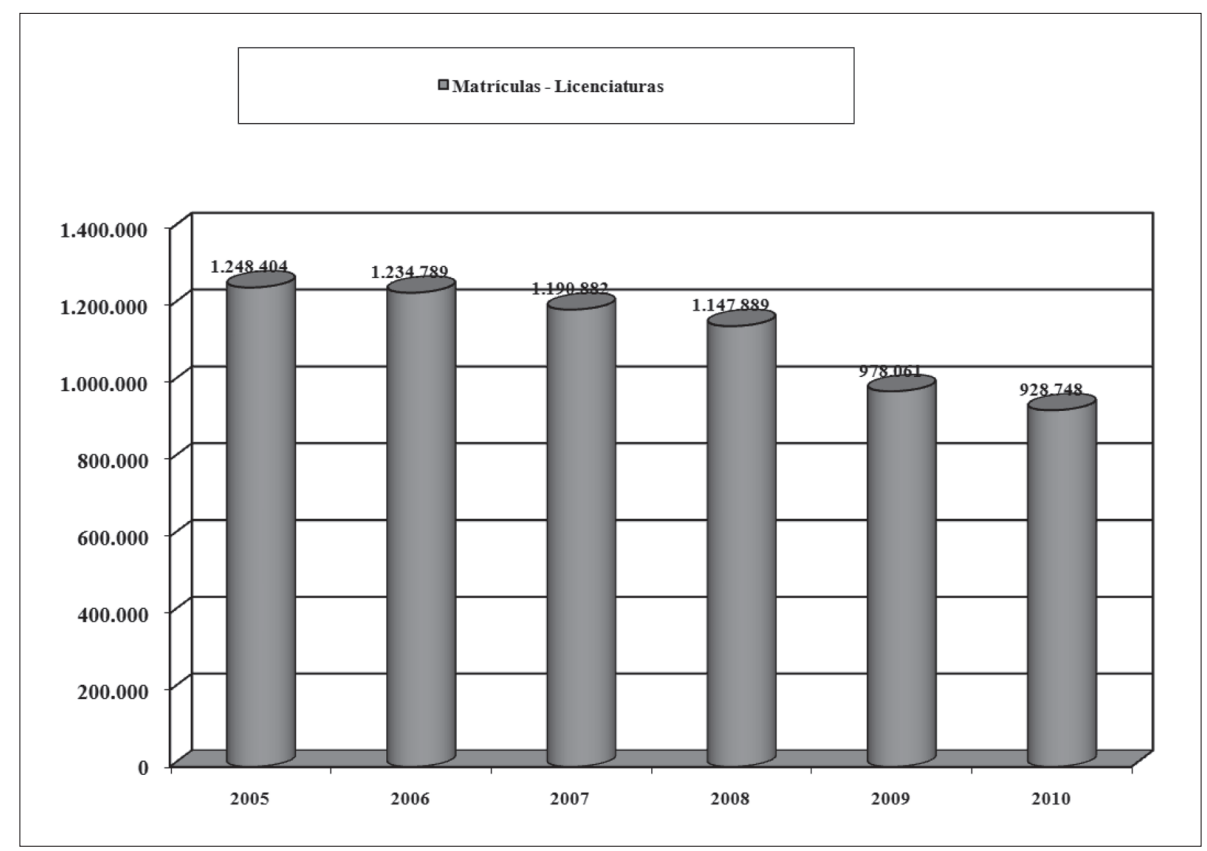

Fonte: INEP/MEC - Censo da ES.

É evidente que, com esta tendência nas matrículas, o número de concluintes dificilmente crescerá nos próximos anos a menos que novas ações, mais arrojadas e focadas, sejam empreendidas pelo governo federal e por todas as unidades da federação.

Há, no entanto, questões ainda mais sérias a serem observadas no comportamento das matrículas da ES como um todo. Com o recente aperfeiçoamento do Censo da ES, que passou a coletar os dados por Cadastro de Pessoa Física (CPF) do aluno, estamos diante de novas revelações. Apesar do crescimento das matrículas, acima destacado, quando se observa a faixa etária dos estudantes, percebe-se que o crescimento atual vem dando-se não com pessoas da faixa etária apropriada (18 a 24 anos), mas com pessoas mais velhas e, muitas vezes, bem acima desta faixa. Ver quadro a seguir: 


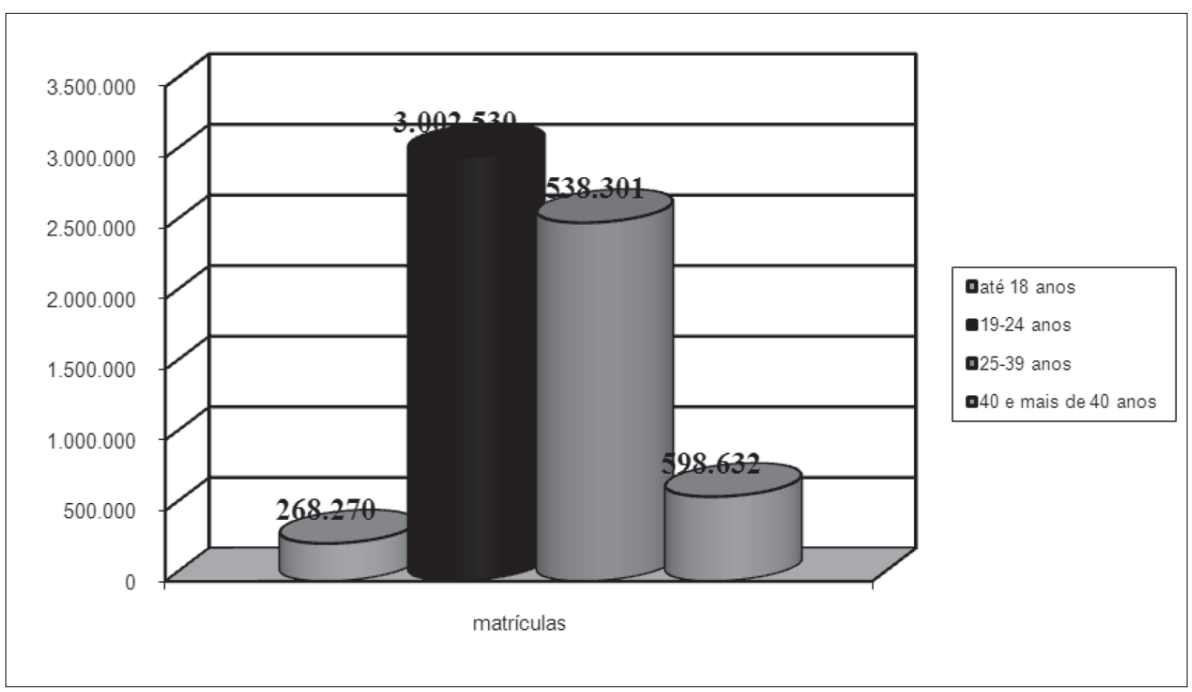

Fonte: INEP/MEC - Censo da ES 2010.

Isto equivale a dizer que dos 6.379.299 estudantes matriculados na ES somente 3.271.628 (51\%) estão na faixa etária considerada apropriada. Desnecessário destacar que estes novos dados têm implicação direta sobre o cálculo da taxa de escolarização líquida da ES, que com os dados da faixa etária correta de todos os matriculados cai de 16,6 para $14,2 \%$, bem abaixo, portanto, dos $30 \%$ preconizados pelo último PNE.

Chama também atenção o fato de que quase 600 mil estudantes brasileiros matriculados na ES têm mais de 40 anos de idade. Se por um lado fica evidente que a democratização do acesso à ES está trazendo para o campus pessoas que historicamente estavam excluídas ou, ainda, que se abrem oportunidades para que pessoas já graduadas façam um novo curso superior, é também verdade que surgem dúvidas sobre o aproveitamento efetivo da democratização por aqueles que deveriam ser os seus principais beneficiários: os concluintes do ensino médio.

Neste sentido, deve-se lembrar que a taxa líquida de escolarização do ensino médio brasileiro, referente aos jovens de 15 a 17 anos, é inferior a 50\%. Mais chocante, no entanto, é perceber que, enquanto crescem as vagas na ES, diminui o número de concluintes do ensino médio, como mostra o quadro a seguir: 


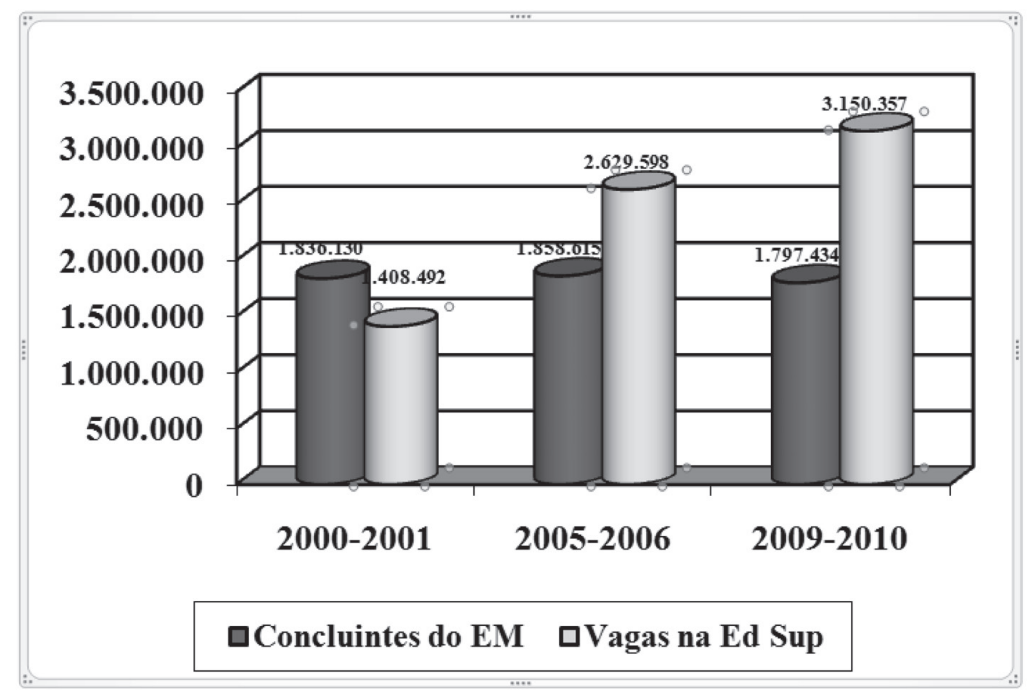

Fonte: INEP/MEC

\subsection{Pelo feito, as evidências do muito a fazer: a título de conclusão}

Fica evidente que, com a diminuição ano a ano dos concluintes do Ensino Médio, o aumento da taxa de escolarização proposto pelo novo PNE (20112020) é apenas um sonho. Ações urgentes, enérgicas e decisivas precisam ser tomadas para trazer um contingente significativamente maior de jovens de 15 a 17 anos para a sala de aula. As medidas bem intencionadas, como a criação do FUNDEB, criação do IDEB, as diversas ações e os diversos Programas da CAPES, são de uma timidez vexatória diante da magnitude do problema educacional que o Brasil enfrenta. Ou o Brasil resolve a sua crise sistêmica e constrói formas efetivas de inclusão dos contingentes marginalizados do ensino médio ou a situação continuará a piorar.

É necessário frisar, por fim, que da ótica da formação de professores, a diminuição de matrículas nas licenciaturas e a diminuição de concluintes no ensino médio é, para dizer pouco, catastrófica, pois anula os enormes esforços até aqui empreendidos na criação do sistema nacional de formação, a implantação do piso salarial nacional e os programas de bolsas e estudos que buscam romper o apartheid entre a PG, a graduação e as escolas. Os dados do relatório de avaliação do PARFOR, feito pela própria CAPES, revelam que o esforço para 
a formação de professores em quantidade suficiente para atender à demanda da EB tem sido recebido com pouco entusiasmo tanto pelas universidades públicas quanto pelos próprios professores atuantes na rede. Ver quadro abaixo:

\begin{tabular}{|r|r|r|r|}
\hline Ano & \multicolumn{1}{|c|}{ Oferta } & Turmas Implantadas & \multicolumn{1}{c|}{ Matriculados } \\
\hline 2009 & 39.841 & 140 & 4.273 \\
\hline 2010 & 73.313 & 787 & 26.689 \\
\hline 2011 & 46.075 & 494 & 19.297 \\
\hline TOTAIS & 159.229 & 1.421 & 50.259 \\
\hline
\end{tabular}

Fonte: CAPES/M| - Diretoria de Educação Básica Presencial

O que os dados revelam é que, após três anos de programa, o PARFOR abriga apenas 50.259 matriculados, tendo apresentado uma oferta de 159.229 vagas. Dizer que isto é uma gota no oceano de problemas não é mera força de expressão. Para um setor que forma, em todo o país, somadas todas as IES, cerca de 1900 professores de Física/ano e cerca de 3.800 professores de Química/ano para uma demanda atual de cerca de 60.000 e para um setor em que todas as disciplinas ministradas, sem exceção, operam com professores improvisados, ou seja, sem a formação específica na área em que atuam e, por fim, num setor, em que todas as regiões do país, de norte a sul e de leste a oeste, apresentam graves carências, o esforço da CAPES, embora tenha que ser reconhecido pelo bom direcionamento que proporciona, é rigorosamente insuficiente e precisa ser repensado e trazido para um novo conjunto de ações que possam mobilizar e despertar a comunidade acadêmica e a sociedade brasileira para as urgências e emergências da EB brasileira, com especial atenção voltada para o ensino médio.

\section{REFERÊNCIAS}

AGUIAR, Márcia Angela da S. ANPEd e Educação Básica: contribuições para a política educacional no Brasil. In: PIMENTEL, Marília A. L. P. (Org.). Memórias da anped. 30 anos. Rio de Janeiro: ANPEd, 2007. 1 CDROM 
BASTOS, Maria Helena C.; MENDES, Luciano (Orgs.). A escola elementar no século XIX. O método monitorial/mútuo. Passo Fundo: Ediupf, 1999.

BIANCHETTI, Lucídio. Pós-graduação na Ibero-América. Conflito de temporalidades e embates Tradição X Modernidade. Perspectiva, Florianópolis, v. 29, n. 2, p. 649-672, jul./dez. 2011.

. Os dilemas do coordenador de Programa de Pós-graduação: entre o burocrático-administrativo e o acadêmico-pedagógico. In: SGUISSARDI, Valdemar (Orgs.). Dilemas da pós-graduação. Gestão e avaliação. Campinas/SP: Autores Associados, 2009.

BRASIL.Ministério da Educação e Cultura. Plano de desenvolvimento da educação (PDE). Brasília: MEC, 2007.

. Lei no. 11.502, de 11 de julho de 2007 (modifica as competências e a estrutura organizacional da CAPES).

. Decreto no. 6.094, de 24 de abril de 2007 (Plano de Metas Compromisso Todos pela Educação).

. Decreto no. 6.316 de 20 de dezembro de 2007 (aprova o Estatuto da Nova CAPES).

. Decreto No. 6.755 de 29 de janeiro de 2009 (institui a Política nacional de formação dos profissionais do magistério para a educação básica).

. Decreto no. 6.095 de 24 de abril de 2007 (cria os Institutos Federais de Educação Tecnológica).

CAMBI, Franco. História da Pedagogia. São Paulo: Editora UNESP, 1999. COMENIUS, João A. Didática magna. Ou da arte universal de ensinar tudo a todos. 3 e. Lisboa: Fundação Calouste Gulbenkian, 1985.

CURY, Carlos R.J. Graduação/Pós-Graduação: a busca de uma relação virtuosa. Educação \& Sociedade, Campinas, v. 25, n. 88, p. 777-793, Especial - out. 2004.

FERRARO, Alceu R. A. ANPEd, a pós-graduação, a pesquisa e a veiculação da produção intelectual na área da educação. Rev. Bras. Educ. Rio de Janeiro, n.30, dez. 2005. 
. SPOSITO, Marília. O desafio de um estatuto científico para a ANPEd (1989-1993). In: PIMENTEL, Marília A. L. P. (Org.). Memórias da anped. 30 anos. Rio de Janeiro, ANPEd, 2007. 1 CD-ROM.

FREITAS, Helena. A (nova) política de formação de professores: a prioridade postergada. Educ. Soc., Campinas, v. 28, n. 100 - Especial, p. 1203-1230, out. 2007.

FRIGOTTO, Gaudêncio. Tendências pedagógicas hoje: educação e trabalho. Prospectiva. Porto Alegre, AOERGS, v. 2, n. 15, out.1986.

HOSTINS, R.C. L. Os Planos Nacionais de Pos-Graduacao (PNPG) e suas repercussoes na Pós-Graduação brasileira. Perspectiva. Florianópolis, v. 24, n. 1, p. 133-160, jan./jun. 2006.

INEP/MEC. Sinopses estatísticas da educação superior. Brasília: INEP, 2005-2010.

. SINAES - Sistema Nacional de Avaliação da Educação Superior. Brasília: INEP, 2003 (ver também a última edição desta publicação, pois a cada edição novas portarias são incluídas).

KUENZER, Acácia Z. Eexclusão includente e inclusão excludente: a nova forma de doualidade estrutural que objetivas as novas relações entre educação e trabalho. In: LOMBARDI, José Claudinei; SAVIANI, Dermeval; SANFELICE, José Luiz (Orgs.). Capitalismo, trabalho e educação. 3 ed. Campinas/SP: Autores Associados, 2005.

LIVRO Azul: $4^{\text {a }}$ Conferência Nacional de Ciência, Tecnologia e Inovação para o Desenvolvimento Sustentável. Brasília: Ministério da Ciência e Tecnologia/Centro de Gestão e Estudos Estratégicos, 2010.

; MORAES, Maria C. M. Temas e tramas na pós-graduação em educação. Educação \& Sociedade, Campinas, v. 26, n. 93, p. 1341-1363, set./dez. 2005.

MANACORDA, Mario A. História da educação. Da antiguidade a nossos dias. São Paulo: Cortez; Autores Associados, 1989.

MENDONÇA, Ana Waleska P. C. A pós-graduação como estratégia de reconstrução da universidade brasileira. Educar em Revista, Curitiba, n. 21, p. 289-308, 2003. 
MERCADO, Edna A. Busca dos fundamentos teórico-históricos do processo de monitoria. Cadernos de METEP, Maringá, v. 4, n. 3, p. 99-113, jan/dez. 1991

ORWELL, George. A revolução dos bichos. São Paulo: Companhia das Letras, 2007.

RIBEIRO, Maria L. S. História da educação brasileira. Organização escolar. 5 ed. São Paulo: Moraes, 1984.

RISTOFF, Dilvo I. Construindo outra educação. Florianópolis: Insular, 2011.

ROMANELLI, Otaiza O. História da educação no Brasil. Petrópolis/RJ: Vozes, 1986.

RUIZ, Antonio Ibañez et al. Escassez de professores no ensino médio: propostas estruturais e emergenciais. Brasília: CNE/MEC, 2007.

SAVIANI, Dermeval. História das ideias pedagógicas no Brasil.

Campinas/SP: Autores Associados, 2007a.

- O plano de desenvolvimento da educação: análise do projeto do MEC. Educ. Soc., Campinas, v. 28, n. 100 - Especial, p. 1231-1255, out. $2007 b$.

. Educação Brasileira: estrutura e sistema. 10 ed. Campinas/SP:

Autores Associados, 2008.

SCHWARZ, Roberto. Martinha versus Lucrécia. Ensaios e entrevistas. São Paulo: Companhia das Letras, 2012.

TAYLOR, Friedirich W. Princípios da administração científica. 7 ed. São Paulo: Atlas, 1989. 